\title{
Material Availability and the Supply Chain: Risks, Effects, and Responses
}

Authors: Elisa Alonso $•$ Frank Field $\downarrow$ Jeremy Gregory $\downarrow$ Randolph Kirchain 


\section{Introduction}

From 1982 to 2002, the price of steel changed on average only 4\% yearly; over the three years 2002 to 2005, steel prices skyrocketed 50\% (1). Price swings like these throughout the raw materials sector have placed a renewed spotlight on the implications that raw materials can have on a firm and supply chain operations.

The importance of raw materials is obvious to those stakeholders that operate upstream (Figure 1) extracting, refining, and processing material into products; such stakeholders are intimately aware of the vagaries of material supply and prices. However, it is critical that all stakeholders become aware of the potential impact of raw material supplies on their business. If those raw materials become difficult to acquire, market forces may shift demand to other goods and therefore other supply chains.

Irrespective of one's specific business, such shifts can lead to irreparable economic harm. Unfortunately, the post facto responses available to firms are limited by the far-reaching effects of materials. Materials are not simply a bundle of characteristics that translate into product performance. Instead, on the operational side, materials establish a class of appropriate production technologies and, by extension, possible product forms and architecture. From the perspective of supply chain management, materials dictate the set of possible suppliers and, therefore, the distribution of supply chain nodes. The extent of these effects means that soley reactive response will be limited and may be ineffective.

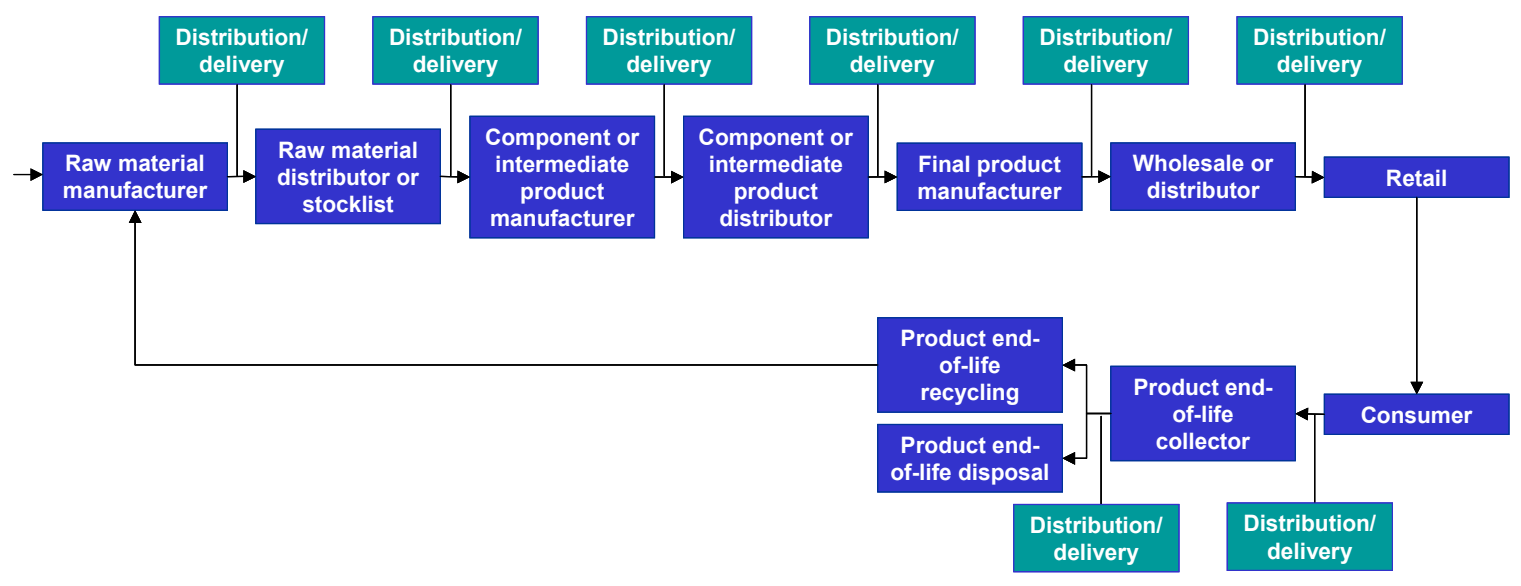

Figure 1: Supply chain diagram from upstream raw material manufacturer to downstream retail and reverse supply chain which includes disposal and recycling. 
In light of this, supply chain stakeholders, should be aware of the stresses that supply chains place on materials use and the vulnerability of the supply base for that material to change. The question of materials availability is an issue that has been addressed many times over the past 200 years by scientists, engineers and economists, and it is an issue with many levels of complexity. This document examines the question of materials vulnerability, or conversely materials availability, from the perspective of a supply chain decision-maker. Specifically, it addresses four elements of this question:

- Outcomes: What types of changes can be observed in supply chains as a result of limited materials availability?

- Mechanisms: What can cause supply chains to face limited raw materials availability?

- Metrics: How can supply chain decision-makers screen for materials availability vulnerability?

- Strategies: How can supply chains adapt to become more resilient to potential limited materials availability?

This paper, through the use of detailed case analyses, suggests that there are specific outcomes technological, operational, and geographic - which can be expected within supply chains when limitations on materials emerge and that at least two mechanisms can drive limited access to materials. These results are complemented with an examination of metrics to diagnose vulnerability and a preliminary discussion of preventative prescriptions for the supply chain.

\subsection{An Overview of Issues for the Supply Chain}

To understand how supply chain policy-making may be altered by awareness of materials constraints, it is first necessary to characterize both the impact that such constraints can have on supply-chain operations (outcomes) and the mechanisms by which these constraints are realized. Although the details of these will be explored subsequently, they are summarized here to provide the context from which their symptoms and prevention emerge.

\subsubsection{Outcomes from Limited Materials Availability}

There are at least three types of outcomes that may result from a material shortage:

1. Technological: Supply chain stakeholders may redesign their products to use less or substitute materials.

2. Geographic: The upstream supply chain may reconfigure to tap into new sources

3. Operational: Downstream firms may alter inventory practices or work to recover alternative materials streams. 
The supply-chain for the residential construction industry provides a clear and easily accessible case that demonstrates all three of these effects. Lumber shortages in the U.S. Northeast, in part due to the booming housing industry, have resulted in increasing costs of lumber (NY Times (2)). To some extent, construction companies have passed on the costs to customers. However, some firms have adapted to these changes by exploring other technological options, including engineered wood, steel studs, and reinforced concrete. Options for alternative sources, Canada, were limited due to government-imposed quotas. Interestingly, as recent prices for other materials have risen (most notably steel), construction firms are moving back away from those substitutes (3). Clearly, those firms with the skill to make use of other material options were better positioned to deal with these fluctuations in material prices.

The effects of materials availability on the construction industry supply chain are very visible because of the large tonnages (4) and the high degree of technological substitutability ${ }^{1}$. However, all product supply chains are vulnerable to materials availability problems, but not all firms have configured their technological and operational options to adapt to these vulnerabilities.

\subsubsection{Mechanisms that Drive Availability Risk}

Based on the case presented in the next section and review of the literature, there appear to be at least two prominent mechanisms that can create materials availability risk. This document proposes that one mechanism - institutional or structural efficiency - exists that can be expected to trigger adverse supply chain outcomes. Institutional inefficiency has been largely overlooked in the traditional analysis of materials availability due to its ephemeral nature. However, although the disruption may be short-term, it may result in permanent and significant changes to the supply chain and the patterns of materials use that it supports.

The second mechanism, physical limitation or constraint, has been the focus of the economics and environmental literature around materials availability (5-10). Conceptually, a material is considered physically scarce when there is a risk of "running out". More generally, physical constraint concerns involve apprehension that long term world demand will exceed world supply.

\footnotetext{
${ }^{1}$ Successful firms offering substitutes to softwood lumber go to great length to make their products compatible with traditional construction methods. Any deviation from this is addressed through extensive education to overcome barriers to adoption ((3) Garth, J.; Eastin, I.; Edelson, J.; CINTRAFOR, 2004.).
} 


\section{Historical Case Study:}

\section{Global outcomes from decreased availability of cobalt in the 1970's ${ }^{2}$}

Historically, no documented case of significant global material depletion has occurred. Nevertheless, supply chains have been impacted by specific examples of materials availability during the $20^{\text {th }}$ century ${ }^{3}$. This section examines one such case, the use of cobalt, , to better understand how materials can affect supply chains and to suggest how to identify vulnerability to such risks.

\subsection{Overview of the Case ${ }^{4}$}

Cobalt has always been a material with a volatile price. In fact, from 1966 to 1976 and from 1980 to 2002, the year-to-year price changes of cobalt were as high as $41 \%$. However, even these levels of variability were small compared to the shock felt by the market in the late 1970's. Between 1977 and 1979, the price of cobalt increased 380\%, climbing from $\$ 5.20 / \mathrm{lbs}$ to $\$ 25 / \mathrm{lbs}$ $(\$ 11440 / \mathrm{t}$ to $\$ 55000 / \mathrm{t})$. The price spike occurred following a rebellion in Zaire ${ }^{5}$, a country which at the time represented only $0.04 \%$ of world population and $0.009 \%$ of global GDP (17). This

${ }^{2}$ Information on historical events and data for this section were taken from the following references and sources:

(11) Natural Resources Canada, 1886-2004.,

(12) U.S. Geological Survey; U.S. Department of the Interior, 1932-2006.,

(13) Blechman, B. M.; Sloss, D. National security and strategic minerals : an analysis of U.S. dependence on foreign sources of cobalt; Westview Press: Boulder, 1985.,

(14) Odorn, L. C. T. P.; Institute, C. S., Ed.; U.S. Army Command and General Staff College: Fort Leavenworth, Kansas, 1993.,

$$
\text { Adelman, K. L. The Royal African Society, Oxford University Press 1978, 77, 36-44.. }
$$

\footnotetext{
${ }^{3}$ Many of the examples of materials availability disruptions occurred due to intentional and punitive actions of nations. For example, copper availability in the U.S. was closely linked to policies during the wars of the $20^{\text {th }}$ century. For more details see Appendix A in (16) Jolly, J. L.; 4th ed. ed.; Copper Development Association Inc.: New York, 2005; p 78.

${ }^{4}$ A timeline of the events linked to the "Cobalt Crisis" can be found in the Additional Resources Section (URL dspace).

${ }^{5}$ Zaire is today named the Democratic Republic of Congo
} 
price swing squeezed numerous global supply chains. In response, products, production technologies, sourcing routes, and even national policies were changed.

To explore this example more fully this section will give a background on the cobalt market, describes the events surrounding the "Cobalt Crisis", and discusses the outcomes within the materials supply chain.

\subsection{Background: cobalt sources and applications}

To many, cobalt sounds like an exotic metal with limited practical value. However, cobalt was and is used in a broad array of products for both commercial and consumer applications (Table 2). In the early 1970 's, $40 \%$ of world land-based cobalt reserves ${ }^{6}$ were located in Zaire. Consequently, Zaire and neighboring Zambia controlled about $2 / 3$ of world production. The major mines were located in the Shaba province (cf. Figure 2) with the Benguela railway, which passed through Angola, representing the main transport path for cobalt export.

\footnotetext{
${ }^{6}$ Reserves, as defined by the USGS, incorporates economic and identified ore bodies: (12)

U.S. Geological Survey; U.S. Department of the Interior, 1932-2006..
} 


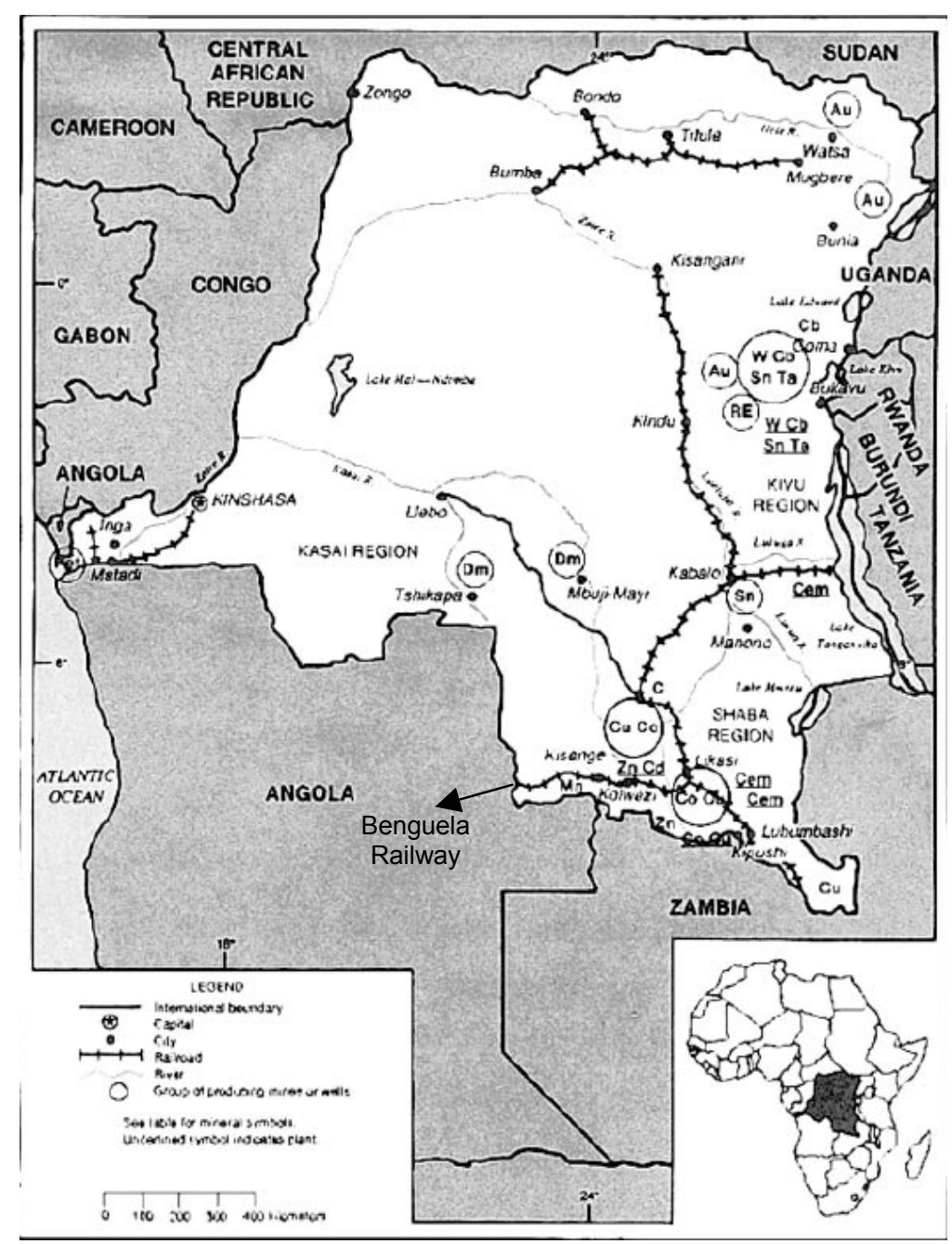

Figure 2: Map of cobalt-producing region of Zaire. Source: http://minerals.usgs.gov/minerals/pubs/country/maps/92449.gif (12).

During this period, the U.S. was the main world cobalt consumer and produced no primary cobalt domestically. One single dealer, African Meta Corps (AMC), supplied all Zairian cobalt to the U.S.

\subsection{Political events surrounding the "Cobalt Crisis"}

Following World War II, the U.S. recognized the strategic importance of cobalt to a number of defense related applications and began to stockpile cobalt as a part of the strategic materials reserve. . From the late 1940's, up until 1973, the U.S. kept a defense stockpile that was about 2 times its yearly commercial consumption. The actual stockpile inventory at the end of 1973 was of 63Mlbs, the U.S. yearly consumption was $18 \mathrm{Mlbs}$. In 1973, the U.S. decided to decrease its stockpile goal to $11.9 \mathrm{Mlbs}$ and to start selling cobalt to U.S. consumers. 
Political instability in the region was of concern in 1975, when the Benguela railway was closed due to a civil war in Angola. As a result, a longer route had to be taken and consumer concern led to increases in consumer stocks. Nevertheless, the supply disruption of cobalt from the downstream supply chain viewpoint was limited because sales from the U.S. defense stockpile continued to supply U.S. cobalt needs.

Continued uncertainty in the region led AMC in 1976 to apply temporary limits to its U.S. cobalt shipments to $125 \%$ of previous 15 months shipments. The U.S. government, concerned with cobalt source instability and defense needs, decided to restock its defense stockpile and set a new goal of $85.4 \mathrm{Mlbs}$. Sales were ceased from defense stockpiles with stockpile inventory at $41 \mathrm{Mlbs}$. In addition, in 1977, there was an increase in U.S. commercial aircraft engine production and in gas-well drilling leading to increases in U.S. cobalt consumption. Still, prices from 1975 to end of 1976 only rose from $\$ 4$ to $\$ 5.40(\$ 8800 / \mathrm{t}$ to $\$ 11880 / \mathrm{t})$.

In March 1977, a first invasion of the Shaba province by about 1500 rebels occurred. The invasion lasted for 80 days and although no major cities were overtaken, operations were disrupted in a manganese mine site in Western Shaba.

A second invasion occurred in May 1978, with 5000 insurgents taking over parts of the Shaba province. They cut the main power line to all mining facilities in the Kolwezi area of the Shaba province. Also, emergency power supplying the Kamoto mine, an underground mine in the region, was cut, leading to flooding of the mine. About 200 of the 2500 European expatriates (many of whom were mining expert contractors) were killed and the remaining were evacuated.

Overall, the insurgents were in Zaire for about 2 weeks. Electrical power to the mines was lost for a total of 5 days. Due to flooding and the evacuation of most expert contractors, the mines in the area were slow to restore operation and the Kamoto mine was unable to return to full capacity for 2 months. Despite all of these issues, Zaire managed to produce more cobalt in 1978 than the average yearly production for the years 1975 to 1977.

However, during this same time period, there was a global economic upturn that led to increased demand for many primary commodities, including cobalt. This, concern for supply shortages, along with real delays in transporting cobalt out to Western countries, led to consumer panic buying and speculation. In the months following the invasion there was a dramatic price increase of cobalt. In February 1979, the price of cobalt hit $\$ 25 /$ lbs $(\$ 55000 / \mathrm{t})$ with dealer prices reported at $\$ 45 /$ lbs $(\$ 99000 / \mathrm{t})$. Prices remained high until 1982 (cf. Figure 3). 


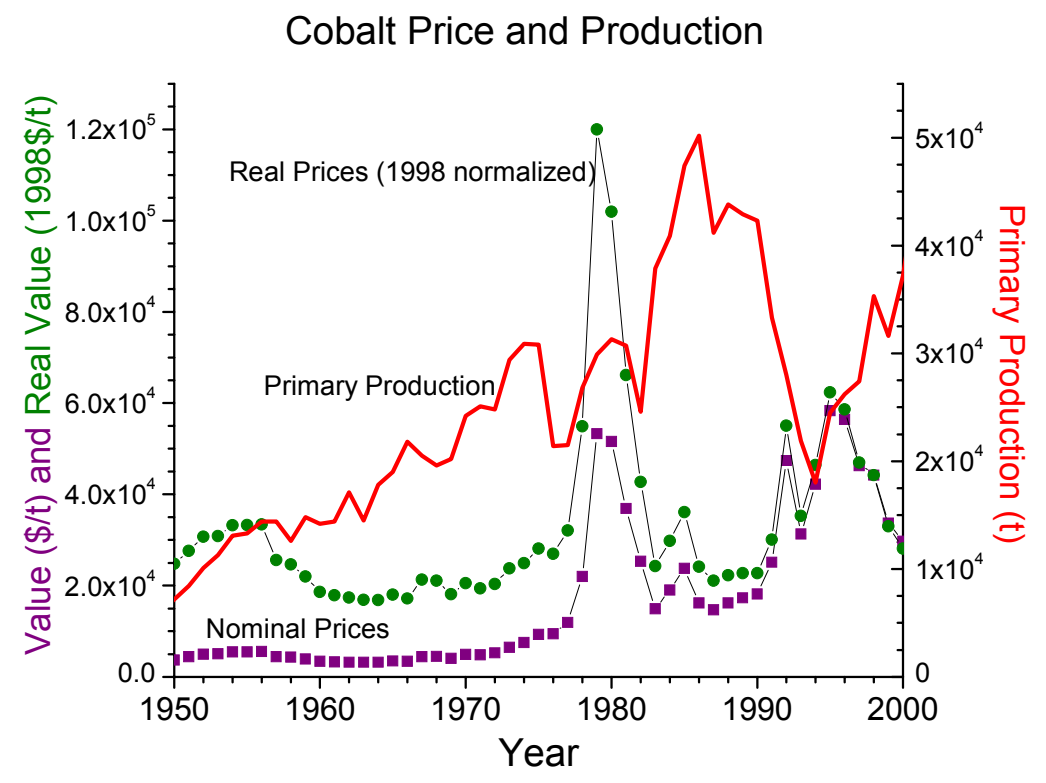

Figure 3: Historical cobalt average yearly prices and primary production 1950-2000 (12).

\subsection{Outcomes of the "Cobalt Crisis"}

During the period of high cobalt prices, interest in reducing the world's vulnerability to cobalt price volatility led cobalt supply chain stakeholders and consuming country governments to act. Emphasis here will be one the supply chain responses.

\subsubsection{Upstream responses}

One set of outcomes was initiated upstream, by raw material manufacturers. Short-term efforts concentrated on improving the lead times that had increased due to the political disturbance. This included transporting some of the cobalt out of the region by air to major world markets.

Longer-term efforts in Zaire were aimed at stabilizing and expanding existing mining operations primarily through the assistance of loans obtained from the World Bank and the Libyan Arab Bank. Zambia, Zaire's neighbor and the world's second largest primary cobalt producer, increased its production capacity by adding to its refining capacity and by improving recovery techniques. A new refinery was opened in Zambia in December 1979 and further increased capacity was expected for 1984 . 
The U.S. mining companies considered their own resources, including the re-commissioning the defunct Black Bird mine in Idaho and ocean floor nickel-manganese nodules. Most effective was the increase in recycling efforts, resulting in a doubling of cobalt recovery after $1978^{7}$.

In the short term, the search for new primary sources of cobalt did not lead to a large change in the importance of Zaire's mining operations; but it did change the location of refining to neighboring Zambia (cf. Figure 4).

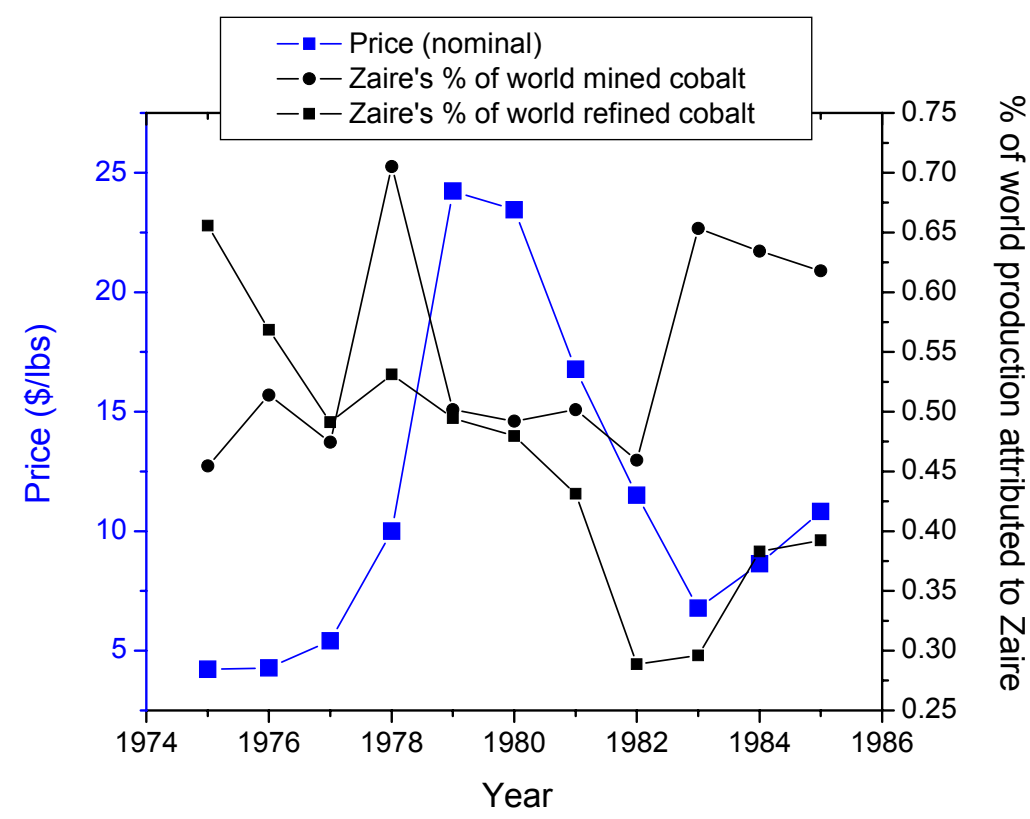

Figure 4: Cobalt prices and changes in Zaire's market share of cobalt supply (12).

In the long term, the U.S. did not pursue any options to increase domestic production since the drop in prices in the 1980's made domestic mining uneconomic. Nevertheless, other changes did occur that reduced the importance of Zaire's mining of cobalt. Specifically, both Zambia and Australia dramatically increased their primary production capacity such that by 2004, Zaire only accounted for $31 \%$ of world mined cobalt. (cf. Table 1 ).

\footnotetext{
${ }^{7}$ Secondary materials can be viewed as an alternate source of raw material - rather than turning to additional sources of ore, the cobalt supply chain turned to secondary sources in the form or recycling. An interesting aspect of secondary materials is that the source location is usually near the consumption location and therefore changing from primary materials to secondary materials is a mode of source relocation.
} 
Table 1: Cobalt primary production geographic distribution (12).

\begin{tabular}{|c|c|c|c|}
\hline Country & $\begin{array}{c}\text { Market Share in } \\
\mathbf{1 9 7 5}(\mathbf{\%})\end{array}$ & Country & $\begin{array}{c}\text { Market Share in } \\
\mathbf{2 0 0 4} \mathbf{( \% )}\end{array}$ \\
\hline Zaire & 47.6 & Congo (formerly Zaire) & 30.5 \\
\hline Australia & 9.2 & Zambia & 19.1 \\
\hline Zambia & 8.1 & Australia & 12.8 \\
\hline New Caledonia & 7.0 & Canada & 9.9 \\
\hline Morocco & 6.8 & Cuba & 6.9 \\
\hline
\end{tabular}

\subsubsection{Downstream responses}

Another set of outcomes emerged downstream in the supply chain, when component and product manufacturers reevaluated their production options in light of the price increases. The specific changes in cobalt consumption patterns are outlined in Table 2.

In the magnetic applications of cobalt, Alnico, an aluminum, nickel, cobalt alloy was the alloy of choice before 1978. Rare-earth-cobalt magnets were already being developed and showed great promise in replacing Alnico because they were stronger and used less material. (Minerals Yearbook 1977 (12)). When prices did spike, substitution to rare-earth-cobalt occurred quickly in the magnet industry in applications with limitations on weight, size and energy.

Reduction of cobalt use in superalloys for the aerospace industry was more difficult because of limited available substitutes and because there was increased demand for jet engines. In the short term, cobalt consumption in the transportation industry increased, with only some substitution to nickel-based alloys. Nevertheless, some savings in cobalt use were attained with development of a recycling process for using scrap superalloy.

Some substitution to iron-based and nickel-based alloys also occurred in cobalt cutting tools, however, overall machinery end-use of cobalt increased slightly. Reduction in cobalt consumption in ceramics and paints also occurred, likely because substitution in these applications was easy. 
Table 2: Changes in cobalt uses from 1975 to 1981 (Appendix B, Table B-3 (13)).

\begin{tabular}{|l|c|c|c|c|c|c|}
\hline \multirow{2}{*}{\begin{tabular}{l} 
Cobalt $\begin{array}{l}\text { Consumption } \\
\text { End-Use }\end{array}$ \\
\cline { 2 - 7 }
\end{tabular}} & $\begin{array}{c}\text { Q1975-1977 average } \\
\text { Quantity } \\
\text { (Mlbs) }\end{array}$ & $\begin{array}{c}\text { 1978 } \\
\text { Quantity } \\
\text { (Mlbs) }\end{array}$ & $\begin{array}{c}\text { \% } \\
\text { Q }\end{array}$ & $\begin{array}{c}\text { Quantity } \\
\text { (Mlbs) }\end{array}$ & $\%$ \\
\hline Transportation & 3.5 & 30 & 4.6 & 23 & 5.8 & 36 \\
\hline Electrical & 4.4 & 20 & 4.6 & 23 & 2.8 & 17 \\
\hline Machinery & 2.9 & 17 & 3.3 & 16 & 3.0 & 19 \\
\hline Paints & 2.7 & 16 & 3.8 & 19 & 2.1 & 13 \\
\hline Chemicals & 1.6 & 9 & 2.2 & 11 & 1.7 & 11 \\
\hline Ceramics & 1.8 & 10 & 1.6 & 8 & 0.6 & 4 \\
\hline Other & 0.5 & 3 & 0.3 & 1 & 0.2 & 1 \\
\hline \hline Total & 17.4 & & 20.4 & & 16.1 & \\
\hline
\end{tabular}

\subsection{Summary: lessons learned}

Cobalt was selected for this case study because it is pointed example of the range of outcomes that can result for supply-chains as a result of material availability disruptions. In particular, as prices rose, the supply-chain responsed through.

- materials substitution and development of new technology

- source relocation

- hoarding and rationing

- supply mode changes

Some supply chain responses reduced and while others increased the negative effects of the supply disruptions.

- Downstream supply chain efforts were generally positive. Consumption of primary cobalt was decreased by material substitution and increased recycling.

- Upstream supply chain efforts to find new sources of cobalt were not particularly fruitful. However, relocation of cobalt refineries to neighboring Zambia insulated parts of the supply chain (especially employees) from political instability

- Imposed ration allocations by the sole Zairian cobalt supplier only increased market uncertainly and possibly extended the length of the disruptions.

- Although, the U.S. government held stockpiles of cobalt and was an important second source of cobalt, it could not continue supplying the U.S. market in the long term. The government's decision to stop sales from the stockpile and restock in 1976 resulted in a sudden decrease of domestic supply and increase of demand, resulting in a sudden change of the cobalt market.

- Supply chain managers decisions to change transportation path improved lead times in the short-term.

The events surrounding the supply disruption highlight the factors that influence materials vulnerability to institutional inefficiency. Three issues increased the effect of the disruption: 
- poor geographic distribution of sources

- monopsony market conditions and

- lack of substitutions for critical applications, in this case defense-related applications

A large aspect of the price spike was based on speculation, related to the fact that Zaire alone controlled such a large part of the global primary cobalt market. The factors that influenced cobalt vulnerability may serve as indicators of the possibility for institutional inefficiency. These metrics will be covered in detail in the next section. 


\section{Identifying and Measuring Vulnerability to Availability Problems}

The first key challenge for supply chain decision-makers is identifying vulnerable elements of their own supply chains. To begin to address this question, this section describes a range of metrics that provide insight into materials market vulnerabilities.

Of course, the use of any metric carries with it a host of assumptions that require careful scrutiny. The reduction of a complex circumstance to a single number necessarily depends upon a simplified abstraction that is limited by the assumptions used to devise the model. While no single metric can capture the complexity of reality, the careful application of metrics can generate important insights into not only where problems might be expected to emerge, but also where concern need not be quite so intense.

The following figure (cf. Figure 5) illustrates much of the complexity confronting the constructor of resource scarcity metrics.

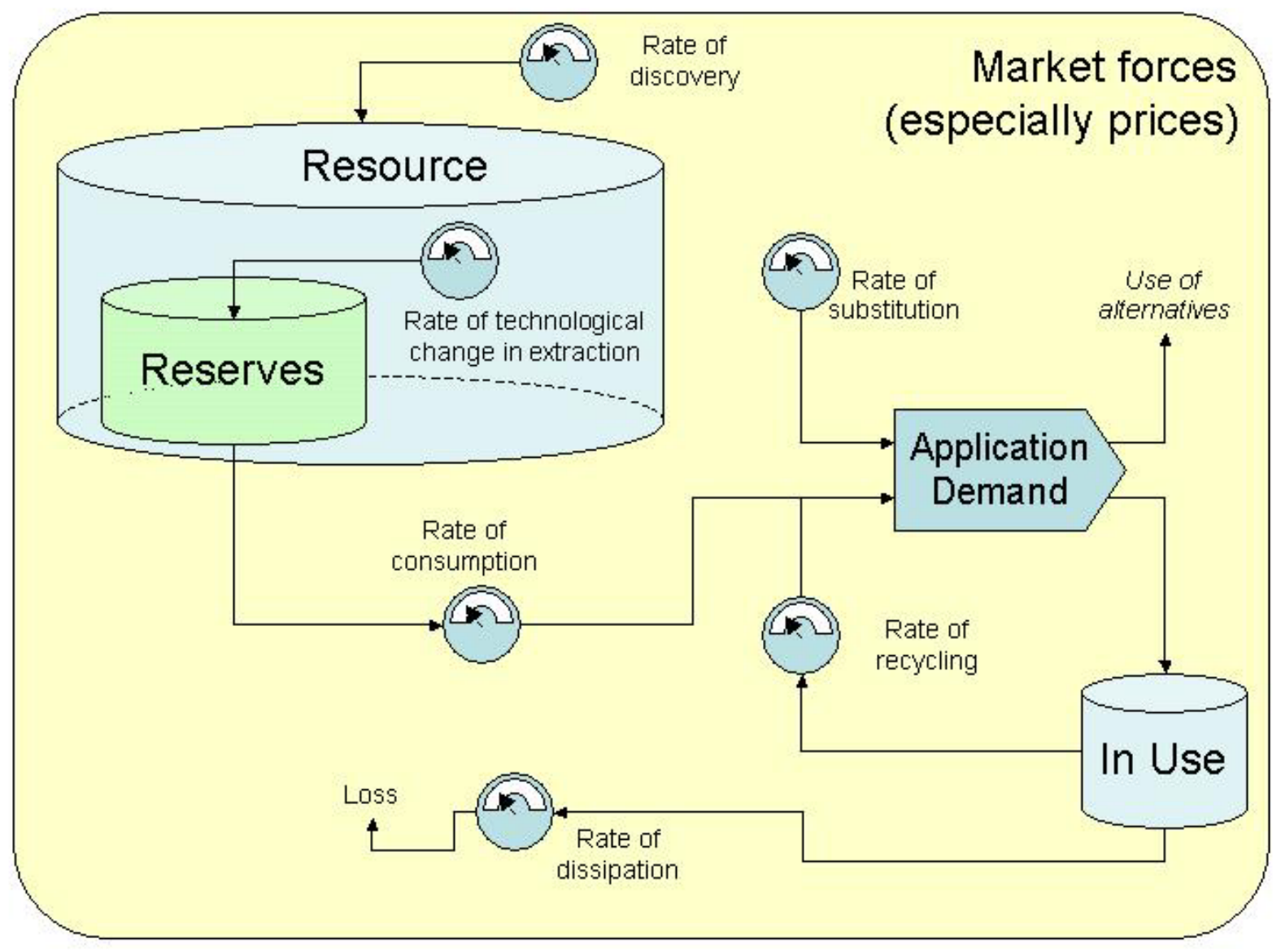

Figure 5: Flow analysis for materials availability. Key drivers of scarcity/availability are indicated by rates. 
The figure depicts the materials economy as a network of resource flows, driven by a consumption rate deriving from the demand for applications that use the resource, and moderated by the availability of substitutes and recycling rates. Underlying much of this dynamic are market notions, not only in terms of the segregation between resource and reserves ${ }^{8}$, but also in terms of the way in that resource prices will influence demand, substitution and recycling rates.

The figure suggests that, when constructing a metric of scarcity, there are a host of competing rates, which can also be viewed as "drivers of availability," that have to be assessed against the amount of extracted and as-yet unextracted resource:

- resource discovery,

- technological change in extraction ${ }^{9}$

- consumption,

- $\quad$ substitution,

- recycling, and

- $\quad$ loss

\footnotetext{
${ }^{8}$ Geologists subdivide primary sources of metals by how well they have been identified and measured and by how economic and technically viable it is to extract them today. USGS reports global estimates of reserves, reserve base and resources, defined as follows:

The reserves incorporate all ore bodies that are economically and technically viable to extract. The reserve base incorporates reserves, but also includes ore for which extraction is marginally economic and demonstrated subeconomic with present prices and technologies. The resources include the reserve base and the rest of the subeconomic deposits as well as estimates of the quantity of metal that have not yet been properly measured. (reference:(12) U.S. Geological Survey; U.S. Department of the Interior, 1932-2006.)

The resource base includes all metal content in the earth's crust (to a certain depth) and oceans, at all concentrations. (reference: chapter 3 of (18) Tilton, J. E. On borrowed time? : assessing the threat of mineral depletion; Resources for the Future: Washington, DC, 2003.)

${ }^{9}$ We use the term "technological change in extraction" to include technological developments in the production of a given metal that can result in improved access to the metal and thus reduced cost of extraction. In decreasing the cost of extraction, the size of the reserves is increased without an increase in the price of the metal.
} 
None of these rates can be considered fixed, and all are strongly influenced by market and other forces.

The most fundamental question of metric construction is "what does it mean for a resource to be 'scarce'? We have proposed (Section 1.1.2) two mechanisms that result in materials scarcity:

- institutional inefficiency: failures by markets, firms and governments can result in a set of immediate circumstances of resource unavailability

- physical constraints: the amount and quality of a resource is physically determined and ultimately limits materials availability

The cobalt case in the preceding section illustrates how scarcity can arise from purely institutional mechanisms --- in that case, a local disruption of supply that led to a global market disruption. More conventional notions of scarcity can be traced at least as far back as the writings of Thomas Malthus (19). In his presentation, scarcity arises from physical constraints on resource availability, occurring when extraction results in a complete exhaustion of resources. In the early $19^{\text {th }}$ century, economist David Ricardo refined this notion of physical constraints, based on the observation that resources exist in different levels of quality. Because high quality resources will be extracted before lower quality ones, scarcity is not merely a consequence of resource exhaustion, but instead derives from the increasing difficulty and cost of accessing lower quality resources (20). A resource, then, becomes "scarce" when effort needed to access the marginal amount of material is greater than the amount of effort one would be capable of or willing to exert.

Given these perspectives on the mechanisms underlying the notion of scarcity, the metrics presented in this report are classified as either:

- Strict measures of institutional efficiency

- Strict measures of physical constraints: Malthusian metrics, or

- Measures of physical constraints mediated by institutional efficiency: Ricardian metrics

\subsection{Institutional inefficiency metrics}

As the cobalt case study demonstrates, short-term problems, even in isolated areas of the world, can result in global disruptions to the supply of a material. Some scarcity metrics that derive from notions of institutional efficiency are outlined in Table 3. 
Table 3: Measures of institutional efficiency.

\begin{tabular}{|c|c|c|}
\hline $\begin{array}{l}\text { Metrics and } \\
\text { Indicators }\end{array}$ & Description & Source \\
\hline $\begin{array}{l}\text { Geographic } \\
\text { Structure based on } \\
\text { Supply }(\%)\end{array}$ & $\begin{array}{l}\text { Distribution of reserve size in top countries } \\
\text { Assumption: supply diversity increases efficiency }\end{array}$ & (21) \\
\hline $\begin{array}{l}\text { Geographic } \\
\text { Structure based on } \\
\text { Production }(\%)\end{array}$ & $\begin{array}{l}\text { Distribution of production in top producing } \\
\text { countries } \\
\text { Assumption: supply diversity increases efficiency }\end{array}$ & \\
\hline $\begin{array}{l}\text { Institutional } \\
\text { Structure based on } \\
\text { Production }(\%)\end{array}$ & $\begin{array}{l}\text { Distribution of control by most important company } \\
\text { Assumption: supply diversity increases efficiency }\end{array}$ & (22) \\
\hline $\begin{array}{l}\text { Institutional } \\
\text { Structure based on } \\
\text { Consumption }(\%)\end{array}$ & $\begin{array}{l}\text { Distribution of applications and companies that } \\
\text { consume a given material, identification of new uses } \\
\text { of the material } \\
\text { Assumption: demand diversity increases efficiency }\end{array}$ & \\
\hline $\begin{array}{l}\text { Recycling Rate } \\
(\%)\end{array}$ & $\begin{array}{l}=(\text { old }+ \text { new scrap }) / \text { total consumption, or old } \\
\text { scrap/total } \\
\text { Assumption: reliance upon recycled resource } \\
\text { increases efficiency; greater confidence in supply }\end{array}$ & $(12,23)$ \\
\hline $\begin{array}{l}\text { Old Scrap } \\
\text { Availability } \\
\text { (unitless) }\end{array}$ & $\begin{array}{l}\text { Availability = old scrap generated/total } \\
\text { consumption } \\
\text { Assumption: reliance upon recycled resource } \\
\text { increases efficiency; greater confidence in supply }\end{array}$ & $(23,24)$ \\
\hline $\begin{array}{l}\text { Economic Metric: } \\
\text { Market price }(\$)\end{array}$ & $\begin{array}{l}\text { Time trend and volatility of price. } \\
\text { Assumption: efficient markets }\end{array}$ & $(9,25)$ \\
\hline
\end{tabular}


The most broadly-cited measures of vulnerability to institutional inefficiency focus on concentration within the supply-chain. Chapman and Roberts examine concentration from a national perspective, while McClements and Cranswick looked at concentration at a firm level.

In the cobalt case, the structure, both geographic and industrial, of supply and demand affected short term material availability. Generally, the geographic distribution of reserves depends on the geophysics of the earth's crust, past depletion and present exploration. Consequently, resource distribution is uneven and, in most cases, extraction is concentrated in a small number of countries. In and of itself, this is not a problem. However, in the face of uncertain external factors (such as political events, natural disaster, or institutional responses to market structure), concentrations in resource availability make that resource more susceptible to institutional inefficiency and supply disruptions (21). Likewise, oligopsonistic resource markets are more vulnerable to fluctuations in demand, leading to market volatility.

In $1975,45 \%$ of world primary cobalt was produced in Zaire. Cobalt was not uniquely positioned in terms of the geographic distribution of its production (Figure 6a). However, at a $45 \%$ share, actions by a few institutions in the face of political disturbances had a global impact on the cobalt market.

While metal production is more evenly distributed around the world today (Figure 6b), platinum and magnesium appear to be highly vulnerability to institutional inefficiency because, in both cases, a single country accounts for more than $70 \%$ of global production. Moreover, while magnesium resources are evenly distributed around the world, more than $80 \%$ of present platinum reserves are found in South Africa (12).

Copper, lithium and tin exhibit an intermediate, but noteworthy level of vulnerability, in that each has between 35 and $45 \%$ of their primary production concentrated in a single country. 


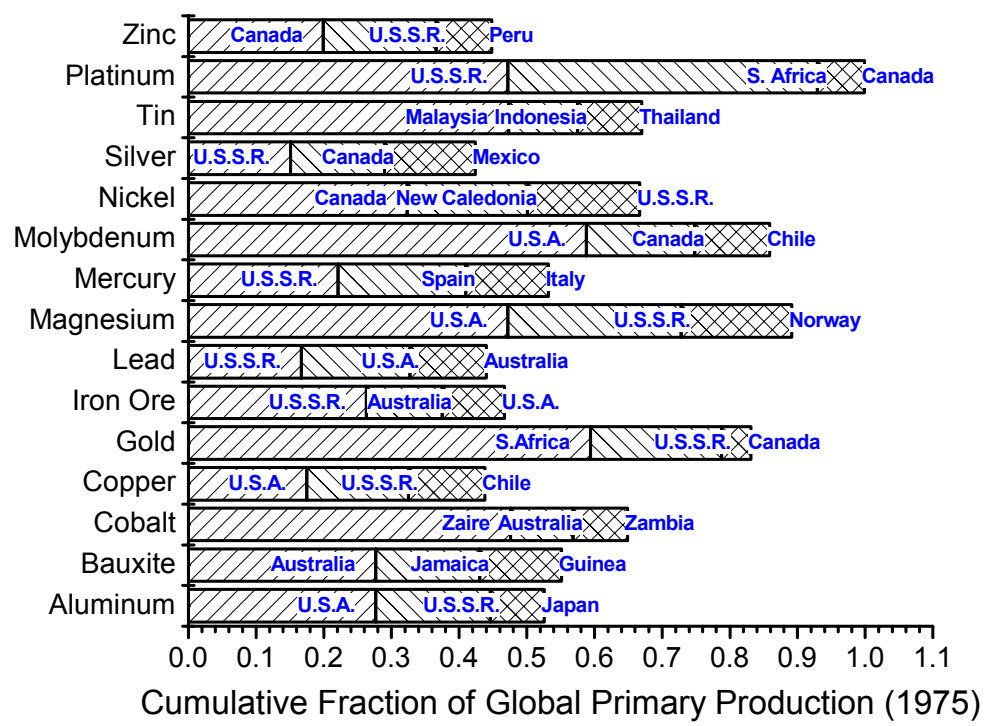

a.

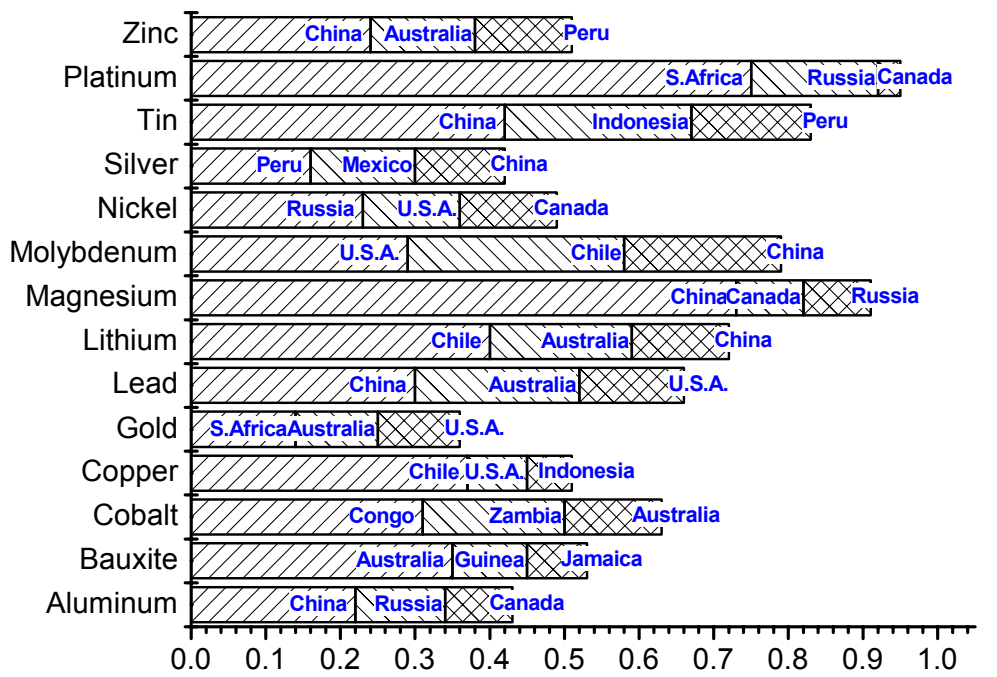

Cumulative Fraction of Global Primary Production (2004)

b.

Figure 6: Geographic distribution of primary production for various metals. Top three producing countries for each metal in a. 1975 and b. 2004.(12)

An examination of the availability of secondary sources yields another perspective on supplychain concentration. In the cobalt case, recycling became an important supply source. Recycling rate can be an indicator of the importance of scrap as a resource (12). Thus, higher recycling 
rates can be an indicator of lower vulnerability. Moreover, high recycling rates in countries with high consumption rates often indicate lower dependence on imported metal since scrap is often collected locally.

Recycling rate data is readily available for the U.S. and can also be found (or derived) for many other countries (cf. Table 4). Lead, which is easily recovered from its predominant application in lead-acid batteries, has the highest recycling rate. Zinc, on the other hand, has a low recycling rate because many of its uses are dissipative.

Recycling rate does not reflect the quantity of metal being discarded at end-of-life, which is treated by the secondary availability metric used by Ayres et al. (24). Availability limits recycling rate if the amount of metal reaching end-of-life is much smaller than demands for that metal. This has been suggested for copper, which has experienced exponential consumption growth rates $(24,26)$.

In the end, materials with high levels of concentration in primary production should be less vulnerable to scarcity arising from institutional inefficiency if there is an active secondary recovery industry.

Table 4: Recycling rates for a few important metals.

\begin{tabular}{|l|c|c|}
\hline & $\begin{array}{c}\text { Global Recycling Rate (1999) } \\
\mathbf{( 2 7 )}\end{array}$ & $\begin{array}{c}\text { U.S. Recycling Rate (average } \\
\text { 2000-2004) (12) }\end{array}$ \\
\hline Aluminum & $29 \%$ & $36 \%$ \\
\hline Copper & $35 \%$ & $31 \%$ \\
\hline Lead & $55 \%$ & $79 \%$ \\
\hline Nickel & $>40 \%$ & $40 \%$ \\
\hline Steel & $>50 \%$ & $56 \%$ \\
\hline Zinc & $>18 \%$ & $26 \%$ \\
\hline
\end{tabular}

The final metric of institutional inefficiency listed in Table 3 is the market price of the commodity of interest. As a number of authors have indicated, price is one of the best measure of scarcity insofar as the market embeds many of the issues outlined above (9). Unfortunately, the volatility of price signals makes them poor leading indicators, particularly for technological development decisions. For example, cobalt prices doubled over a period of 4 months; far less time than was needed to develop alternative materials and processes. As such, while price will ultimately be the trigger that initiates a change in firm strategy it is not satisfactory as a leading indicator of risk. 


\subsection{Malthusian metrics}

The outcomes arising from institutional inefficiency in the cobalt case could also have occurred from physical constraints (21). In this section and the next, metrics drawn from literature will be briefly discussed, but their interpretation will be made through the case study on copper availability.

The direct approach to measuring vulnerability to geophysical limits is to compare how much there is with how fast it is being consumed. This is an extension to the type of analysis used by Malthus (19). These metrics for scarcity are attempting to balance a notion of the total amount of a resource $(\mathrm{R})$ that is available against the rate at which that resource is being consumed (r-dot). The typical metric could be $\mathrm{N}$ in the following equation (1):

$R-\int_{0}^{N} \dot{r} \cdot d t=0$

Assuming $\mathrm{R}$ and $\mathrm{r}$-dot are constant, $\mathrm{N}$ is simply the time to consume the current resource at the current rate. Realistically, none of these terms are ever constants, and assumptions must be made to construct more defendable metrics of geophysical limits. Table 5 presents a set of Malthusianinspired metrics from the literature. The metrics are divided into two broad categories (static or dynamic) depending on the degree to which they treat the dynamic nature of the many interrelated rates in the analysis (see Figure 5). 
Table 5: Direct measures of physical constraint (Malthusian approaches to scarcity).

\begin{tabular}{|c|c|c|c|}
\hline & Metrics & Description & $\begin{array}{l}\text { Source \& } \\
\text { comment }\end{array}$ \\
\hline \multirow{2}{*}{$\stackrel{U}{\underset{E}{E}}$} & $\begin{array}{l}\text { Static Index } \\
\text { of Depletion } \\
\text { based on } \\
\text { Reserves } \\
\text { (years) }\end{array}$ & $\begin{array}{l}\text { Time to consume reserves at constant consumption } \\
\text { rate: Reserve/(present consumption rate); } \\
\boldsymbol{d}_{\boldsymbol{s}}=\boldsymbol{R} \boldsymbol{s} \boldsymbol{V} / \boldsymbol{C}_{\text {present }} \text {. Also referred to R/P index. } \\
\text { Assumptions: consumption rate constant; discovery } \\
\text { and recycling rates negligible; reserves appropriate } \\
\text { basis for consideration }\end{array}$ & \multirow[t]{3}{*}{$\begin{array}{l}(19,27,28) \\
\text { Can be based on } \\
\text { reserve, reserve } \\
\text { base, resource or } \\
\text { resource base. }\end{array}$} \\
\hline & $\begin{array}{l}\text { Static Index } \\
\text { of Depletion } \\
\text { based on } \\
\text { Resources } \\
\text { (years) }\end{array}$ & $\begin{array}{l}\text { Time to consume resources at constant consumption } \\
\text { rate: Resource/(present consumption); } \\
\boldsymbol{d}_{\boldsymbol{s}}=\boldsymbol{R} \mathbf{s} \boldsymbol{C} / \boldsymbol{C}_{\text {present }} \text {. } \\
\text { Assumptions: consumption rate constant; discovery } \\
\text { and recycling rates negligible; resources } \\
\text { (economically recoverable reserves) appropriate basis } \\
\text { for consideration }\end{array}$ & \\
\hline 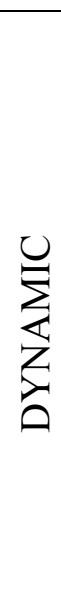 & $\begin{array}{l}\text { Exponential } \\
\text { Index of } \\
\text { Depletion } \\
\text { based on } \\
\text { Reserves } \\
\text { (years) }\end{array}$ & $\begin{array}{l}\text { Time to consume reserves at constant exponential } \\
\text { growth of consumption rate: Reserve/(projected } \\
\text { consumption), where future consumption can be } \\
\text { modeled as having exponential growth; } \\
\boldsymbol{d}_{\mathrm{e}}=\frac{1}{\boldsymbol{r}} \ln \left(\boldsymbol{r} \frac{\boldsymbol{R} \boldsymbol{v} \boldsymbol{V}}{\boldsymbol{C}_{\mathrm{o}}}+1\right) \text {, where } \mathrm{r} \text { is rate of growth } \\
\text { Assumptions: consumption rate exponential; discovery } \\
\text { and recycling rates negligible; reserves appropriate } \\
\text { basis for consideration }\end{array}$ & \\
\hline
\end{tabular}




\begin{tabular}{|l|l|l|l|}
\hline $\begin{array}{l}\text { Relative rates } \\
\text { of discovery } \\
\text { and } \\
\text { extraction } \\
\text { (unitless) }\end{array}$ & $\begin{array}{l}\text { Ratio of rate of discovery to rate of consumption } \\
\text { Assumption: rate of increase in discovery smaller than } \\
\text { rate of increase in extraction/consumption; } \\
\text { recyprovement in extraction technologies negligible }\end{array}$ & $(29)$ \\
\hline $\begin{array}{l}\text { Time to peak } \\
\text { production } \\
\text { (years) }\end{array}$ & $\begin{array}{l}\text { Time until this forecast peak is reached: based on } \\
\text { models of future rates. }\end{array}$ & $\begin{array}{l}\text { Assumption: rate of net consumption (demand less } \\
\text { substitution) will grow faster than rates of discovery, } \\
\text { technological improvement and recycling/reuse }\end{array}$ \\
\hline
\end{tabular}

The indices of depletion have been used and discussed by many, including $(27,28)$. The static index of depletion is an estimate of years to depletion based on the present consumption pattern and one of the four estimates of supply (reserve, reserve base, resource, resource base). The dynamic index of depletion is a simple extension that includes changing consumption rate, for which expected consumption is derived from data for a given historic period and an estimate of supply (reserve,...). A material is considered more vulnerable if it has a low index of depletion.

A major advantage to using the Malthusian approach is its simplicity: depletion is related to how fast a non-renewable resource is consumed. Moreover,the metrics can generally be derived from readily available historical data.

Time frame estimates have been made based on 2004 data for a few important metals (cf. Table 6). Based on the static index, bauxite, iron and cobalt all have time frames greater than 100 years before physical constraints become an issue. Copper, gold and lead have much shorter time frames and would be expected to be more vulnerable.

Dynamic indices are based on growth rates, here calculated from USGS data over a 10 year period. As Table 13 shows, high exponential growth rates greatly affect the time frame for depletion, especially for aluminum and cobalt, whose reserve-based exponential indices are under 50 years. 
Table 6: Static and exponential indices for some metals of interest (12).

\begin{tabular}{|c|c|c|c|c|c|c|c|}
\hline & \multirow[b]{2}{*}{$\begin{array}{l}\text { Reserve } \\
\text { in } 2004\end{array}$} & \multirow{2}{*}{$\begin{array}{c}\text { Reserve } \\
\text { base in } \\
2004\end{array}$} & \multirow[b]{2}{*}{ Resources } & \multirow{2}{*}{$\begin{array}{c}\text { Primary } \\
\text { production } \\
\text { in } 2004\end{array}$} & \multicolumn{3}{|c|}{ static index (yrs) based on } \\
\hline & & & & & reserve & $\begin{array}{c}\text { reserve } \\
\text { base }\end{array}$ & resource \\
\hline $\begin{array}{l}\text { Bauxite } \\
\text { (aluminum) }\end{array}$ & $2.50 \mathrm{E}+10$ & $3.20 \mathrm{E}+10$ & $6.50 \mathrm{E}+10$ & $1.59 \mathrm{E}+08$ & 157 & 201 & 409 \\
\hline Cobalt & $7.00 \mathrm{E}+06$ & $1.30 \mathrm{E}+07$ & $1.50 \mathrm{E}+07$ & $5.24 \mathrm{E}+04$ & 134 & 248 & 286 \\
\hline Copper & $4.70 \mathrm{E}+08$ & $9.40 \mathrm{E}+08$ & $2.30 \mathrm{E}+09$ & $1.46 \mathrm{E}+07$ & 32 & 64 & 158 \\
\hline Gold & $4.20 \mathrm{E}+04$ & $9.00 \mathrm{E}+04$ & unavailable & $2.43 \mathrm{E}+03$ & 17 & 37 & \\
\hline Iron ore & $8.00 \mathrm{E}+10$ & $1.80 \mathrm{E}+11$ & $2.30 \mathrm{E}+11$ & $7.12 \mathrm{E}+08$ & 112 & 253 & 323 \\
\hline Lead & $6.70 \mathrm{E}+07$ & $1.40 \mathrm{E}+08$ & $1.50 \mathrm{E}+09$ & $3.15 \mathrm{E}+06$ & 21 & 44 & 476 \\
\hline Zinc & $2.20 \mathrm{E}+08$ & $4.60 \mathrm{E}+08$ & $1.90 \mathrm{E}+09$ & $9.60 \mathrm{E}+06$ & 23 & 48 & 198 \\
\hline
\end{tabular}

\begin{tabular}{|l|c|c|c|c|}
\hline & $\begin{array}{c}\text { average growth } \\
\text { rate from 1994 } \\
\text { to 2004 }\end{array}$ & \multicolumn{3}{|c|}{ exponential index (yrs) based on } \\
\cline { 3 - 5 } & $4.2 \%$ & 49 & 55 & 70 \\
\hline $\begin{array}{l}\text { Bauxite } \\
\text { (aluminum) }\end{array}$ & $12.0 \%$ & 25 & 30 & 31 \\
\hline Cobalt & $4.4 \%$ & 20 & 31 & 48 \\
\hline Copper & $0.8 \%$ & 16 & 33 & \\
\hline Gold & $0.3 \%$ & 96 & 186 & 222 \\
\hline Iron ore & $1.3 \%$ & 19 & 35 & 153 \\
\hline Lead & $2.8 \%$ & 18 & 31 & 68 \\
\hline Zinc & & & & \\
\hline
\end{tabular}

The above metrics all assume a decreasing supply base for non-renewable resources. However, new discoveries, improved technology and increased recycling have contributed to supply increases in the past. Taking this into account, one can classify materials with a rate of supply growth less than the rate of increasing consumption as vulnerable $(19,29)$. One can also incorporate rates into a model to estimate a time to peak production. Hubbert's peak for oil was one such model (30), which assumed consumption followed a bell curve and that the scarcity would occur when growing demand for a given material can no longer be satisfied.

One criticism of Malthusian metrics is that, since many of the parameters are based on historical data, the effect of new technologies that may increase future demand for a metal is not considered. For example, future development of fuel cells for alternative energy conversion may greatly increase platinum use. 
Most importantly, the choice of defining supply as the reserve or resource appears random without an understanding of the technology and economics of extraction. The differences in source are tied to a Ricardian concept - that of varying quality of source.

\subsection{Ricardian metrics}

The main criticism of Malthusian metrics is their assumption of a fixed global supply at constant quality for a given material. Variations in the quality of a source are tied to the level of effort required to obtain additional metal. Firms will preferentially consume high quality sources and, future availability should decrease with increases in the difficulty of extracting a material. From a Ricardian viewpoint, scarcity should occur long before physical exhaustion (6). Ricardian metrics of global availability, presented in Table 7, are meant to measure scarcity trends.

The ore grade is a simple physical measure of the quality of supply (21): in general, the lower the ore grade, the more earth will be displaced to access the metal, the more energy will be expended to concentrate the mineral, and the more environmental waste will be generated.

A few metals and typical ore grade ranges are given in Table 8 . The ore grades of abundant metals, such as iron, aluminum and titanium, are greater than 10\%. Much less abundant materials, such as silver and platinum group metals, have ore grades that are fractions of a percent.

The main disadvantage to using ore grade as a metric is that the quality of the supply is not entirely captured - for example, an ore body at the surface of the earth's crust is more accessible than one underground. Moreover, ore grade is an imperfect measure of the difficulty of extraction - for example, more energy is required to extract aluminum from bauxite than that required to extract copper from chalcopyrite. 
Table 7: Indirect measures of physical constraint: effort metrics, quality of supply metrics (related to Ricardian approach to scarcity (20)).

\begin{tabular}{|c|c|c|}
\hline Metrics & Description & Source \\
\hline $\begin{array}{l}\text { Average ore grade } \\
(\%)\end{array}$ & $\begin{array}{l}\text { Concentration of metal in a given ore body } \\
\text { Assumptions: efficient markets in factors and } \\
\text { capital; technological efficiency; accessibility } \\
\text { effects negligible }\end{array}$ & $(21,24)$ \\
\hline Cost (\$) & $\begin{array}{l}\text { Sum of technical costs (machines, fuel, labor, } \\
\text { etc.), environmental costs, political costs, } \\
\text { commercial costs (marketing, insurance, stock } \\
\text { dividends) } \\
\text { Assumptions: efficient markets in factors and } \\
\text { capital; technological efficiency }\end{array}$ & $(6,9,21,31)$ \\
\hline Energy cost $(\mathrm{MJ})$ & $\begin{array}{l}\text { Energy cost of extraction } \\
\text { Assumptions: efficient markets in factors and } \\
\text { capital; technological efficiency }\end{array}$ & $(9,21)$ \\
\hline $\begin{array}{l}\text { Labor and capital } \\
\text { inputs per unit of } \\
\text { extractive output } \\
\text { (unitless) }\end{array}$ & $\begin{array}{l}\text { Costs based on extraction costs } \\
\text { Assumptions: efficient markets in factors and } \\
\text { capital; technological efficiency }\end{array}$ & (32) \\
\hline $\begin{array}{l}\text { Economic Metric: } \\
\text { Market price }(\$)\end{array}$ & $\begin{array}{l}\text { Relative price, time trend. } \\
\text { Assumption: efficient markets }\end{array}$ & $(9,25)$ \\
\hline
\end{tabular}


Table 8: Typical ore grades and annual 2004 average price for some important metals (33).

\begin{tabular}{|l|c|c|}
\hline \multicolumn{1}{|c|}{ Metal/mineral } & Ore grade (wt \%) & Price (\$/tonne) \\
\hline Magnesium & $70-95 \% \mathrm{MgCO}_{3}$, brine $3 \% \mathrm{Mg}$ & 3476 \\
\hline Aluminum & $35-50 \% \mathrm{Al}_{2} \mathrm{O}_{3}$ & 1848 \\
\hline Iron & $30-65 \% \mathrm{Fe}$ & 338 \\
\hline Lead & $4-8 \% \mathrm{~Pb}$ & 884 \\
\hline Zinc & $2-4 \% \mathrm{Zn}$ & 1045 \\
\hline Copper & $0.2-5.0 \% \mathrm{Cu}$ & 2860 \\
\hline Nickel & $1.5 \% \mathrm{Ni}$ & 13,823 \\
\hline Tin & $0.5 \% \mathrm{Sn}$ & 8536 \\
\hline Cobalt & $0.4 \% \mathrm{Co}$, byproduct of $\mathrm{Cu}, \mathrm{Ni}, \mathrm{Ag}$ & 52,646 \\
\hline Silver & $0.006 \% \mathrm{Ag}$, byproduct of gold and base metals & 215,088 \\
\hline Platinum group metals & $0.0003-0.002 \%$ PGM, byproduct of Ni-sulfide ores & $27,288,228$ \\
\hline
\end{tabular}

More accurately, the quality of a metal source is related to not only the ore grade, but also the difficulty of extraction. A more direct measure of quality is the cost of extraction because the extraction costs for functioning mines is a direct indication of the resources that institutions are willing to expend to obtain the metal. Increasing extraction costs indicate the changing nature of the available resources and would be expected to correlate with increasing vulnerability $(6,9,21,31)$.

Barriers to using cost as a metric are lack of public data and the subjectivity involved in defining the boundaries (i.e. up to which step are costs incorporated?). Due to the difficulty in obtaining complete cost data, various reports have focused on energy cost or labor and capital costs $(9,21)$. However, these simplifications in cost estimation can weaken the utility of cost as a metric of scarcity.

Metal prices reflect market supply and demand and are sometimes also used for analyzing physical constraints. In this context, price is a Ricardian metric since it is bounded on the lower end by the cost of extraction and, at the upper end, by the amount institutions are willing to pay. Table 8 shows that price generally increases for metals with lower average ore grade.

In general, though, it can be difficult to distinguish price increases due to physical constraints from price increases due to institutional inefficiency (Table 3) such as speculation, temporary disruptions (war, strikes), or artificial manipulation of the market by an oligopoly. Most importantly, from a business perspective, reacting only post facto to increasing prices is a poor mode of managing risk. 


\subsection{Summary of metrics}

Metrics are best used to assess vulnerability rather than predict scarcity since, over the long term, market forces and technology will effectively ensure that responses such as substitution and recycling will occur. The history of mercury shows how market forces directed continued industrial development despite apparent depletion. Using 2004 data, mercury had a static index of 179 years based on reserve base values (12), in contrast with a conclusion drawn a mere 32 years earlier that mercury was already a scarce resource (34).

However, while these mechanisms may ensure that society as a while will transition through changes in materials availability, individual stakeholders within a supply-chain may suffer irreparable harm if they are not aware of and able to respond to such changes. While there were only short term disruptions in the cobalt case study, it presents a good example of how markets and governments can aggravate a situation and change business practices permanently. The cobalt case study also demonstrates that limited materials availability can have a real impact on supply-chain practices and should be included both operational and technological strategies.

Firms need to begin considering their options with regards to materials availability, identifying their reliance on materials with high vulnerability. The metrics identified in this section should be a first step in assessing the vulnerability of a supply chain (Table 9). Identifying materials of interest based on metrics for which data is easily obtained would be an efficient starting point. Once a material of interest has been identified, further in-depth analysis can begin. The next section presents a case study that interprets metrics in the context of the copper supply chain, with emphasis on physical constraints, as industrial efficiency was presented in the cobalt case study. 
Table 9: Summary of important categories of metrics.

\begin{tabular}{|c|c|c|c|c|}
\hline Metric & Mechanism & Advantages & Limitations & $\begin{array}{c}\text { Identified } \\
\text { Vulnerabilities }\end{array}$ \\
\hline $\begin{array}{l}\text { Structure of } \\
\text { Supply }\end{array}$ & $\begin{array}{l}\text { Institutional } \\
\text { efficiency }\end{array}$ & $\begin{array}{l}\text { comparative, based } \\
\text { on historical data }\end{array}$ & $\begin{array}{l}\text { no future predictions, } \\
\text { some data difficult to } \\
\text { obtain }\end{array}$ & $\begin{array}{l}\text { platinum, } \\
\text { manganese, tin, } \\
\text { lithium, copper }\end{array}$ \\
\hline Recycling & $\begin{array}{l}\text { Institutional } \\
\text { efficiency }\end{array}$ & $\begin{array}{l}\text { simple, includes all } \\
\text { sources of metal }\end{array}$ & $\begin{array}{l}\text { recycling rate is not } \\
\text { comparative; some data is } \\
\text { difficult to obtain }\end{array}$ & zinc, copper \\
\hline $\begin{array}{l}\text { Malthusian - } \\
\text { Depletion } \\
\text { indices }\end{array}$ & $\begin{array}{l}\text { Physical } \\
\text { constraint }\end{array}$ & $\begin{array}{l}\text { simple, comparative, } \\
\text { based on generally } \\
\text { available historical } \\
\text { data }\end{array}$ & $\begin{array}{l}\text { lacks understanding of } \\
\text { economic input, does not } \\
\text { directly consider } \\
\text { technology }\end{array}$ & $\begin{array}{l}\text { gold, lead, zinc, } \\
\text { copper }\end{array}$ \\
\hline $\begin{array}{l}\text { Ricardian - } \\
\text { Effort metrics }\end{array}$ & $\begin{array}{l}\text { Physical } \\
\text { constraint }\end{array}$ & $\begin{array}{l}\text { comparative over } \\
\text { time, based on } \\
\text { economic theory }\end{array}$ & $\begin{array}{l}\text { lacks recycling and } \\
\text { substitutability analysis, } \\
\text { some supply-side only } \\
\text { metrics which assume } \\
\text { demand-side will follow, } \\
\text { data difficult to obtain }\end{array}$ & \\
\hline $\begin{array}{l}\text { Economic - } \\
\text { Price }\end{array}$ & $\begin{array}{l}\text { Institutional } \\
\text { efficiency, } \\
\text { Physical } \\
\text { constraint }\end{array}$ & $\begin{array}{l}\text { simple, comparative, } \\
\text { based on readily } \\
\text { available historical } \\
\text { data }\end{array}$ & $\begin{array}{l}\text { assumes informed market, } \\
\text { does not separate } \\
\text { increasing effort and } \\
\text { improved technology }\end{array}$ & $\begin{array}{l}\text { iron, aluminum, } \\
\text { copper, gold, } \\
\text { nickel, zinc, } \\
\text { platinum }\end{array}$ \\
\hline
\end{tabular}




\section{Case Study: copper vulnerability to physical constraint}

This section explores the diagnostic utility of the metrics described in Section 3.. Readers should note that it is not presently possible to know which measures will best forecast vulnerability to geophysical scarcity. Many authors have pointed out that there are no significant examples of broad materials scarcity during the modern era and that even detecting indirect evidence of scarcity is controversial and ambiguous (chapter 1 of (10), (35)). As such, the approach that will be taken here is to examine the consistency of a broad range of indicators - Malthusian and Ricardian - in the context of a specific case study - the use of copper - and to discuss the implications of these metrics for decision-making by supply-chain decision-makers.

Because the cobalt case study specifically examines the issues of institutional efficiency, no treatment of that will be made here other than to refer readers to Figure 6 and the section above on appropriate measures of that form of risk. Several metals, including copper would seem to warrant further investigation in this regard and may warrant close monitoring for further intensification of these institutional mechanisms of material availability risk.

\subsection{Motivation}

Some of the earliest known metal artifacts, dating from around 7,000 BC, are fashioned out of copper (24). Copper's utility has persisted through the intervening eight millennia. In fact, as was shown in Table 6, copper primary production is third highest in terms of annual global tonnage, behind only iron and aluminum. Because of its use in applications such as construction, telecommunications and electricity among other applications (cf. Figure 7), copper use an important indicator of a country's economic growth and development (Ch.2 (10)). 


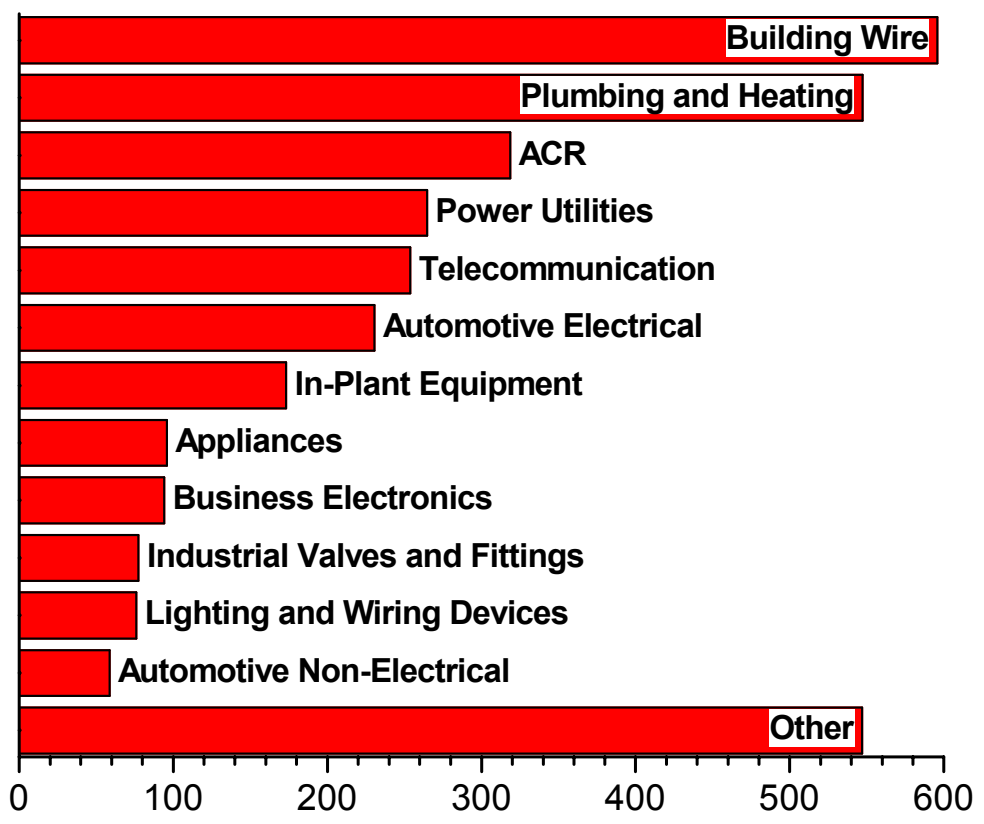

U.S. Copper Uses in 2002 (thousands of tonnes)

Figure 7: Top copper markets in the U.S. in 2002, total copper consumption 3.33Mt; ACR: air conditioning and refrigeration (36).

However, these levels of consumption also lead to apprehension about copper's long-term availability. Specifically, copper's static depletion index, based on reserve base, falls is under 75 years. High economic significance ${ }^{10}$ and a low depletion index positions copper in an area of potential concern compared to other metals ${ }^{11}$, as shown graphically in Figure 8. These

\footnotetext{
${ }^{10}$ Value, while not a metric of scarcity is an indicator of the global importance of a metal. Value here is defined in $\$$ year and is the per tonnage price of the metal * the global primary metal tonnage consumed for a given year (37) MMSD In Mining, Minerals and Sustainable Development; Earthscan Publications Ltd.: London, UK and Sterling, VA, 2002..

${ }^{11}$ Metals in the graph were selected to include top 10 highest tonnage of primary produced yearly metals and top 10 highest annual value (price * tonnage) metals as mentioned in ch.2: (37) MMSD In Mining, Minerals and Sustainable Development; Earthscan Publications Ltd.: London, UK and Sterling, VA, 2002.
} 
characteristics make $\mathrm{Cu}$ a relevant case study into the risk of physical constraint to the supply chain. $^{12}$

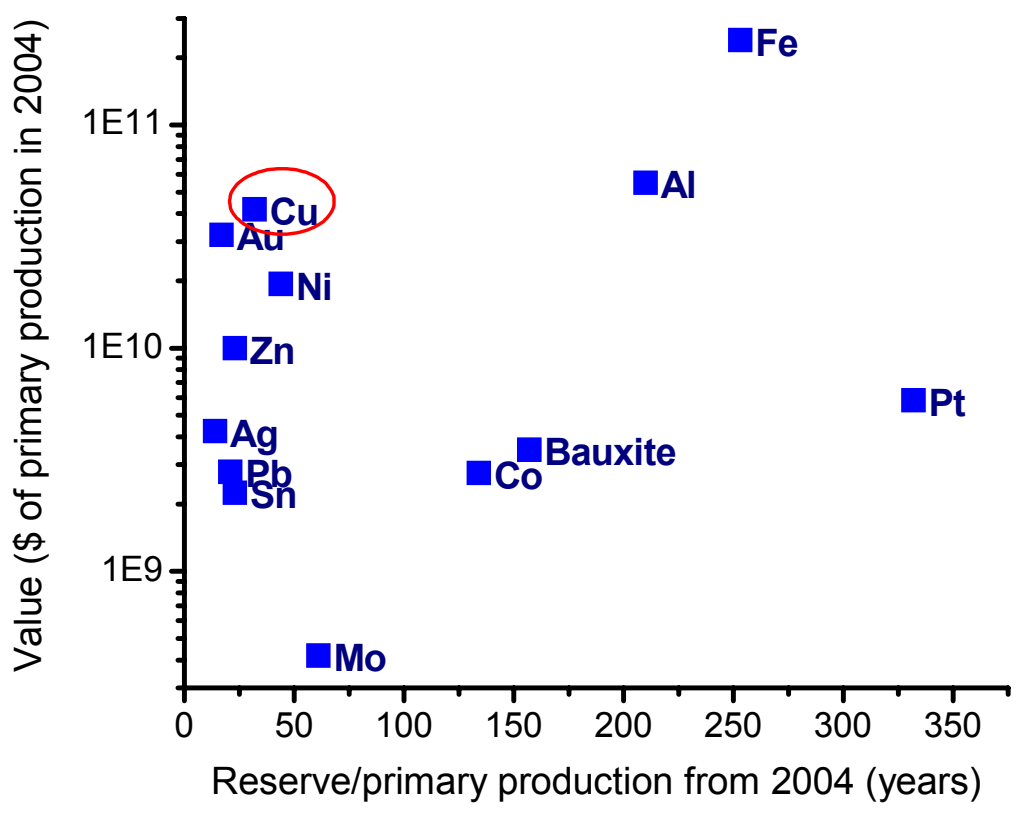

Figure 8: Positioning of metals: Malthusian static index of depletion base on reserves and global value of primary metric (12). Metals of increasing concern have high value and low depletion index.

\subsection{Understanding copper vulnerability using metrics}

Physical constraint of copper, or any non-renewable resource, depends in large part on the drivers of availability: consumption rate, recycling rate, etc. Unfortunately, due to the interdependence of these issues and the fundamental uncertainty of prediction, it is impossible to

\footnotetext{
${ }^{12}$ Copper availability has also been for the subject of case studies in a few published articles and books looking sustainable development. Interested readers may want to consult: ((38) Lifset, R. J.; Gordon, R. B.; Graedel, T. E.; Spatari, S.; Bertram, M. Jom-Journal of the Minerals Metals \& Materials Society 2002, 54, 21-26.), ((24) Ayres, R. U.; Ayres, L.; Råde, I. The life cycle of copper, its co-products and byproducts; Kluwer Academic: Dordrecht ; Boston, 2003.) and ((39) Reijnders, L. Resources, Conservation and Recycling 2003, 38, 59-66.).
} 
measure these drivers directly or with great precision. Nevertheless, decisions must be made. In light of that, this section proceeds by examining (1) a simple, imperfect screening metric, (2) the criteria for action on that metric, and (3) the use of more detailed measures for additional insight on risk.

\subsubsection{Screening for Scarcity Vulnerability: The Static Depletion Index}

The simplest way to screen for scarcity-based material vulnerability is to use static depletion times. Depletion indices based on different measures of geological source - reserve, reserve base, resource and resource base — will be discussed in this section recognizing that the differences among the various measures of source derive from the varying quality of the sources.

Table 10 row 1 shows these screening measures for copper at 2004 consumption rates. Most striking, basing the measure on reserves, the amount of copper available for economic extraction is only sufficient to last 32 years (cf. row 1 of Table 10). This low value contrasts strikingly with those of aluminum and iron, both of which have more than 100 years to depletion at 2004 consumption values (Figure 8).

At the other end of the spectrum, the static depletion index based on resource base is one hundred million years. This indicates that the amount of copper in the earth's crust is so great that any concern for depletion of primary stocks lies in the distant future. However, recall that the resource base incorporates minerals of very poor quality, such that complete extraction would require a prohibitively large energy, capital, environmental and land cost, even in the very long term. 
Table 10: Malthusian metrics: depletion lifetime estimates for copper based on 2004 data.

\begin{tabular}{|c|c|c|c|c|}
\hline \multirow{2}{*}{$\begin{array}{c}\text { Primary Metal } \\
\text { Years to Depletion } \\
\text { based on: }\end{array}$} & Reserve $^{13}$ & Reserve Base & Resource & $\begin{array}{c}\text { Resource } \\
\text { Base }^{14}\end{array}$ \\
\hline & $470,000 \mathrm{kt}$ & $940,000 \mathrm{kt}$ & $\begin{array}{c}1,600,000 \mathrm{kt} \\
\text { (land) + } \\
700,000 \mathrm{kt} \text { (sea) }\end{array}$ & $1.5 \times 10^{12} \mathrm{kt}$ \\
\hline $\begin{array}{l}\text { Static Index: Primary } \\
\text { Production in } 2004= \\
14,600 \mathrm{kt}\end{array}$ & 32.2 & 64.4 & 158 & $1.03 \times 10^{8}$ \\
\hline $\begin{array}{l}\text { Exponential Index: Primary } \\
\text { production * average growth } \\
\text { from } 1969 \text { to } 2004= \\
14,600 \mathrm{kt} \times 2.5 \%\end{array}$ & 23.9 & 38.8 & 64.7 & 598 \\
\hline
\end{tabular}

The most conservative static estimate of 32 years to depletion, based on reserve size, is indicative of the time frame within which new technologies for extraction or new sources must be found in order to continue the present yearly consumption under present economic conditions. Otherwise, changes in economic or technological conditions (increased prices, decreased costs) will occur to reflect the tapping of the reserve base, whose static index is 64 years. Another possible interpretation is that the depletion estimate based on reserve is the time frame within which improved conservation and increased copper substitution will result in decreased copper consumption.

The static depletion time frame estimated based on resource is more than 100 years, greater than the time frame businesses or policy makers need to consider when planning future materials strategies (35). Because the resource size includes inferred copper ores, it embeds a measure of uncertainty. Increased spending on exploration can reduce the uncertainty such that previously inferred ores become determined and can be considered part of the reserves or reserve base. Improved extraction technologies in the future can make previously uneconomic extraction economic. Thus, the estimate based on resource, which assumes that most of the resource can some day be economically accessible, is not unreasonable.

${ }^{13}$ Values of reserve, reserve base, resource and primary production are from USGS Copper Mineral Yearbook 2005 (12) U.S. Geological Survey; U.S. Department of the Interior, 1932-2006.

${ }^{14}$ Value of resource base is from (27) CRU International Ltd. In Mining, Minerals and Sustainable Development; International Institute for Environment and Development: London, UK, 2002; p 221. 


\subsubsection{Limits for concern}

The measures based on reserve, reserve base and resource are considered more informative to supply chain stakeholders, as they better reflect time-frames during which supply-chain decisionmakers have the opportunity to act. Nevertheless, the first question that arises concerning the static depletion indices for copper is whether the values indicate time horizons of concern. In other words, how small a value warrants action? Unfortunately, the real answer to that question derives from the complex interaction of the characteristics of existing deposits, the discovery of unknown resources, the evolution of future demand as well as extraction and production technology, the ability and success of secondary materials recovery, and changes in cost, price and the elasticity of substitution for the material at hand. The development of such models is the subject of active research, but is currently only undertaken for the most valuable of global resources - typically energy resources.

Nevertheless, non-fuel mineral supply-chains must make decisions about when to allocate resources to mitigate material price risks. For this purpose, the authors would propose, an inferential strategy for evaluating the gravity of depletion index screens. In particular, the reserve-based screen should be compared against industry rules of thumb for reserve capacity. Several authors have examined the issues that drive reserve management decisions, particularly exploration and technology development $(18,21)$. Although there is variation in their analyses, all point to a figure of about 30 years for the magnitude of the managed reserve life compared to current consumption. Accumulating stocks beyond that level, generally, does not provide significant discounted revenue to offset the costs of exploration and the vagaries of market evolution. Thus, 30 years may serve as a threshold indicator for concern; greater values would represent conditions where the primary industry is unmotivated to address geophysical scarcity, while values around or below 30 years would indicate a need for further evaluation.

Based on this criterion, copper, with a static depletion index of 32 years, sits on the border of concern, leaving the question as to whether further or more intensive investigation is warranted. In an analysis of oil reserves, Pindyck's modeling results showed significant price increases shortly before any reduction in the R/P (40). In light of this, current information would suggest that strategic decision-makers should pay careful attention to resources whose economic availability sits in this region.

In light of this result, further investigation into the nature of the risk within the copper supply chain seems prudent. The following section to will do so by applying the dynamic Malthusian and Ricardian measures described previously. 


\subsubsection{Further Investigation into Supply-Chain Risk: Dynamic and Ricardian Measures}

\subsubsection{Dynamic Depletion Index}

Since applications that require copper are key to modern industrialization, copper consumption over the past century has continuously increased and is expected to continue increasing as countries in developing East Asia and eventually other parts of the world continue to industrialize. In fact, based on data from (16), covering years 1969-2004, one finds that total copper consumption from primary and secondary sources has increased exponentially $\left(\mathrm{R}^{2}=0.9643\right)$, with ba total increase of $124 \%$ and an average growth rate of $2.3 \%$ (cf. Figure 9 ). Moreover, primary consumption has also grown exponentially during this period $\left(\mathrm{R}^{2}=0.9567\right)$ with an average growth rate of $2.5 \%$.

Extrapolating these consumption growth rates, dynamic measures of depletion time estimate significant depletion within the next century (cf. row 2 of Table 10).

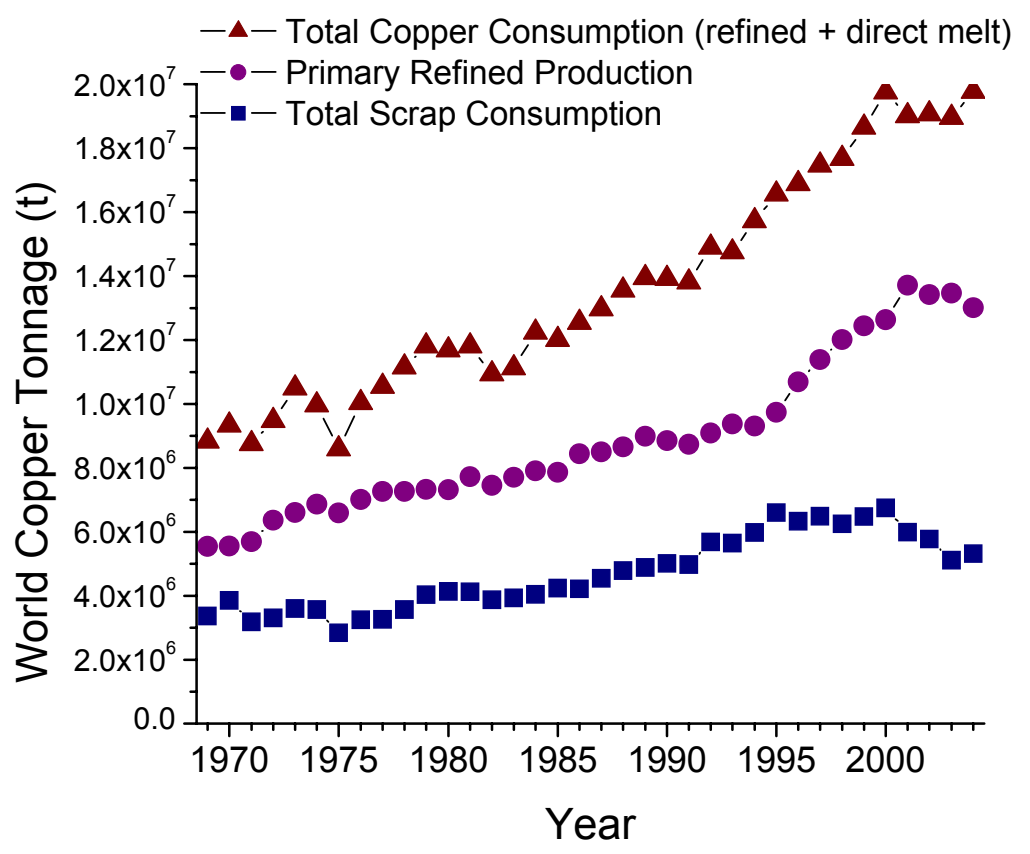

Figure 9: Global copper consumption trends 1969-2005 (16).

\subsubsection{The Nature of The Available Resource}

Malthus' dismal statement regarding food and population growth was made based on the dynamic analysis that population appeared to be growing at a faster rate than the capacity to 
produce food. In the case of copper, concern about consumption trends would be reduced if exploration and recycling rates seemed to match the rate of consumption growth.

Although consumption has been growing exponentially, primary copper producers have, in part through exploration, been able to increase size of reserves (cf. Figure 10). For the past decade, reserve/consumption ratios have sat at the border of concern at slightly above thirty years (cf. Figure 11).

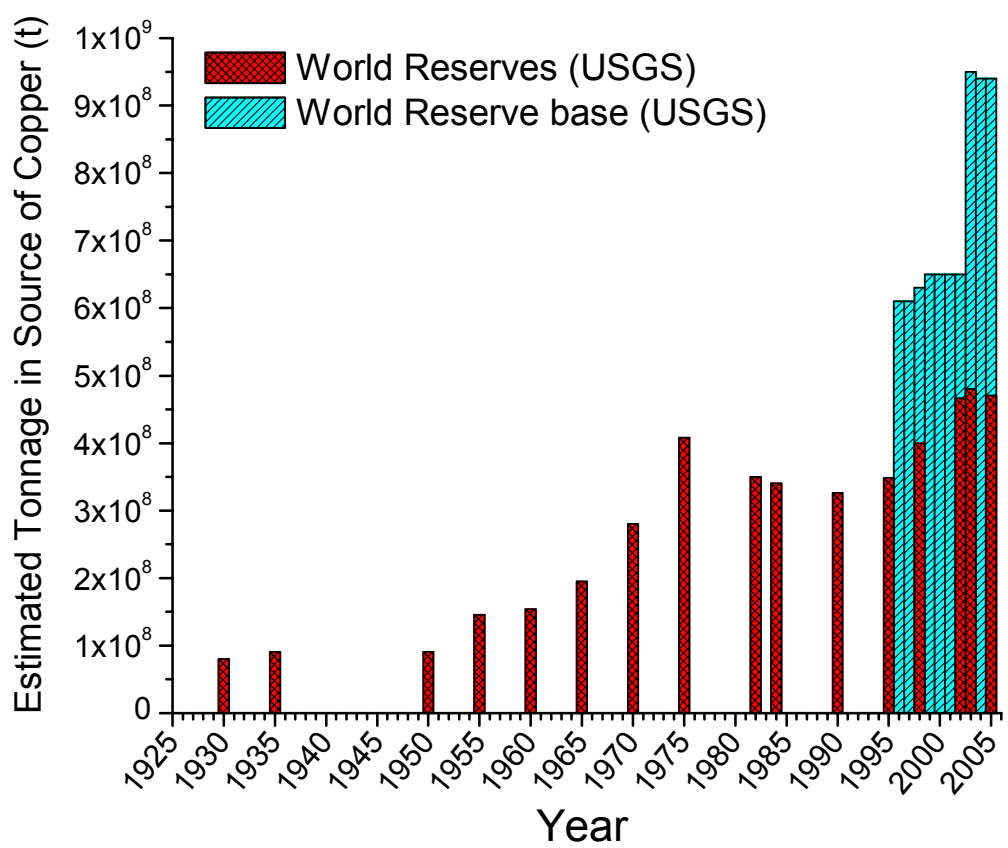

Figure 10: Historical estimates of reserve and reserve base (12). 


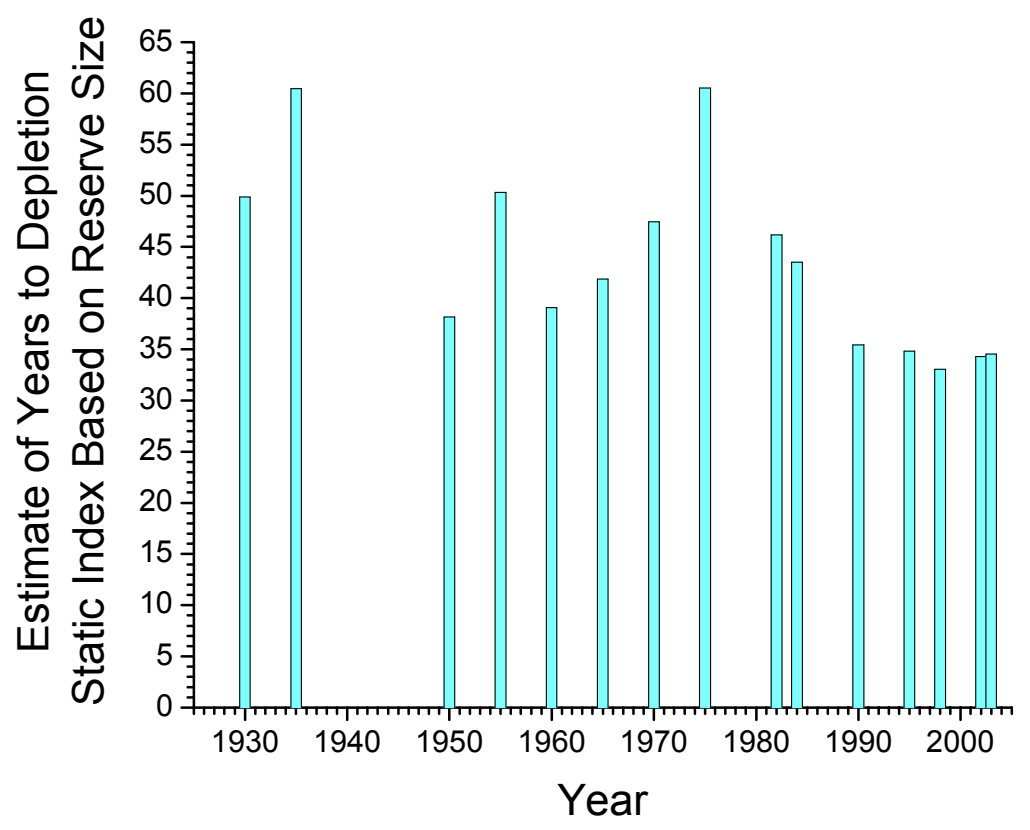

Figure 11: Change over time of estimate of future depletion year based on static index of copper reserve (12). Changes in static index estimate (number of years to depletion).

\subsubsection{Ricardian measures}

Technological improvements have also made it economically feasible to exploit lower grade ores, increasing reserve size and postponing depletion. Between 1970 and 1993, when US copper grade remained a relatively constant $0.5 \%$, the costs of western world copper mining decreased, illustrating the effect of improving technologies (cf. Figure 12) (24,31). Copper prices, which depend in part on costs, also somewhat decreased over the same period of time.

However, overall world cumulative primary consumption since 1770 has been increasing faster than the rate of discovery (29). Moreover, copper ore grade, which is an indicator of the ease of extraction, has decreased for the U.S. since 1980 (24). In fact, Ayres has shown that, from 1880 to 1970 , average copper ore grades for the U.S. dropped from $3 \%$ to $0.5 \%$, plateauing at $0.5 \%$ copper from 1970 to 2000 . 


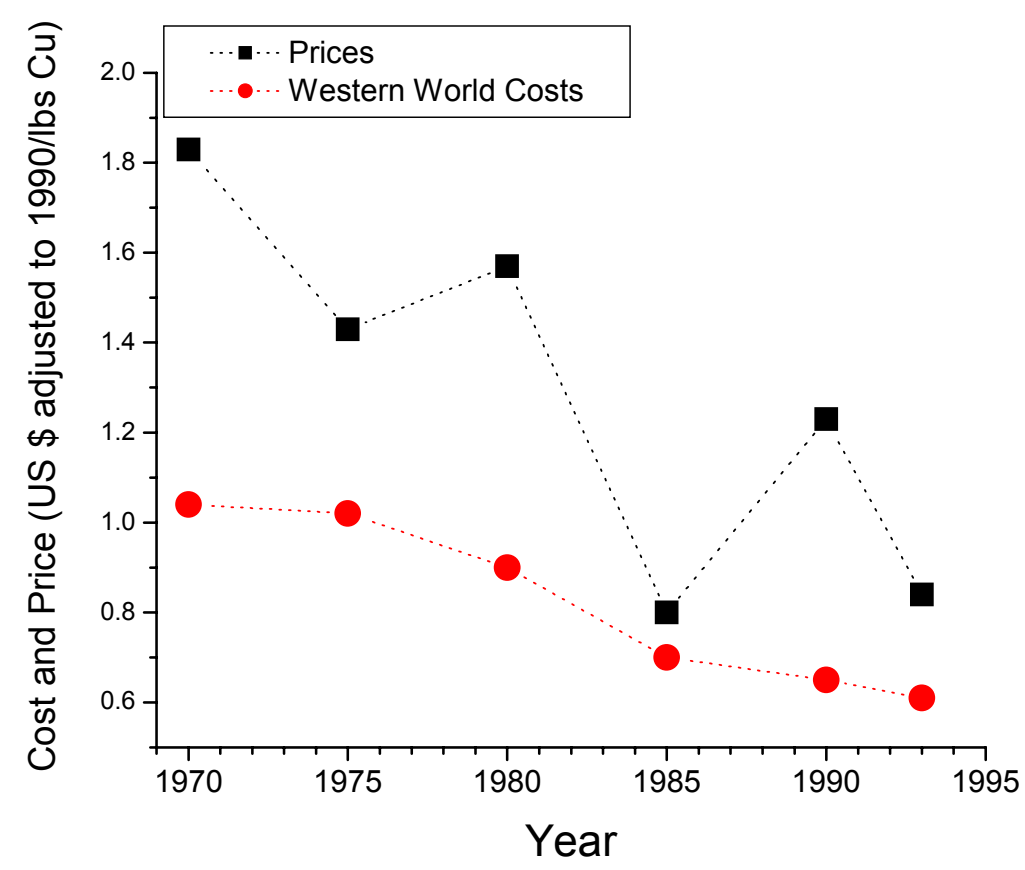

Figure 12: Weighted-average adjusted breakeven costs of producing refined copper metal from primary and prices for the western world for 1970, 1975, 1980, 1985, 1990 and 1993. Costs do not include capital costs. Price is US domestic producer price. Values have been adjusted to real 1990 US dollars. Source: (31).

\subsubsection{The Availability of Substitutes}

Once primary production peaks, secondary production will be the key to preventing significant drops in copper consumption. Analysis of recycling is more difficult, mainly because information for many metals is not publicly available and, in some cases, can vary widely between sources. In 1994, the world recycling rate was estimated to be $22.5 \%$ or $39 \%$, depending on the reference source ((41) and (16), respectively). World recycling of end-of life copper (old scrap) was estimated based on materials flow analysis (MFA) and accounted for only $17.5 \%$ of total consumption (41). According to Graedel et al., copper availability in 1994 was limited to $26.7 \%$ of global copper consumption. One reason for low availability is that copper products have lifetimes of 10 to 45 years, so much of the copper that has been consumed in the past few 
decades is still in use, with more being added yearly to the global infrastructure than being discarded $^{15}$.

Table 11: Copper recycling metrics, based on Graedel 1994 Copper Cycle Flow Diagram. Note: reference Jolly 2005 estimated 1994 recycling rate at 39\%.

\begin{tabular}{|l|l|}
\hline Recycling Rate & $22.5 \%$ \\
\hline Old Scrap Recycling Rate & $17.5 \%$ \\
\hline Old Scrap Availability & $26.7 \%$ \\
\hline Recycling Efficiency & $65.6 \%$ \\
\hline
\end{tabular}

Based on the data from Jolly 2005, secondary consumption from 1969-2004 did increase overall, with old and new scrap combined accounting for between $27 \%$ and $41 \%$ of yearly copper consumption (= recycling rate). However, the overall secondary growth rate was not exponential and the recycling rate did not show any growth. These results indicate that world growth of copper consumption depended heavily on world growth of mine production capacity, rather than recycling increases.

\subsubsection{Modeling Scarcity}

Further understanding of copper availability would involve building a model to measure some of the other metrics that have still not been covered in this analysis: time to peak production and secondary availability.

In the case of copper, a few types of models have been prepared. The concept of peak production is central to the debate on the future of oil, with the Department of Energy (DOE) predicting peak production in 2037 (42). For copper, one estimate for peak production gives a 15 year time frame before copper primary production will no longer be able to continue increasing (24).

The risk of copper disruption is significantly greater than for iron and aluminum, and it has been at a historical high for the past decade. From the simplest metrics based on static measures of depletion to more complex metrics based on modeling, indications of copper vulnerability reinforce the need for firms to adapt to the risk of possible future material disruptions.

\footnotetext{
${ }^{15}$ Copper in infrastructure is defined as copper that is being used in products such as the copper piping in houses that are still standing, or copper in cars that are still being driven. The Use phase identifies $7,800 \mathrm{Gg}(1 \mathrm{Gg}=1 \mathrm{kt})$ of copper that was added to the global infrastructure in 1994.
} 


\subsection{Understanding supply chain roles in addressing copper vulnerability}

What businesses should take from the above analysis is that, while the complete depletion of copper is not imminent, access to the available body of primary resources will require changes. Given rules of thumb of reserve management, a proactive business that depends upon the materials that derive from those reserves will understand that there are actions that they can take and that should be considered to mitigate these changes. Upstream and downstream supply chain stakeholders will have different roles to play in reducing the vulnerability of any material system.

Upstream supply chain stakeholders are well aware of their effect on copper supply. For example, each year, actions taken to increase the size of reserves include:

1. exploration to find new reserves

2. technology improvements to decrease costs of extraction, and

3. technology improvements to increase copper yield from extraction processes

Upstream supply chains have worked towards reducing copper vulnerability by increasing spending on copper exploration from 340M\$ to 825M\$ between 2003 to 2005 ((12) 2004 exploration summary, (43)). These types of efforts have led to a $460 \%$ growth of copper reserves since 1930, despite the exponential growth in primary consumption.

Downstream supply chains also need to address copper vulnerability and should not take comfort that upstream supply chains will ensure continued supply. Businesses that do not prepare themselves for upstream materials disruptions and price increases can become uncompetitive as new, lower cost technologies or materials replace copper. One option to reduce vulnerability is to forestall scarcity. Large consumption growth rates accompanied by low recovery rates greatly increases the risks of scarcity. Therefore, downstream efforts to defer scarcity should involve:

1. technological improvements to increase efficiency

2. technological discoveries to substitute copper for lower cost/lower vulnerability materials, and

3. increased recycling - both at the manufacturing and end-of-life stages In certain cases, these actions may already have been taken to satisfy business efficiency. 


\subsection{Improving resilience towards copper vulnerability}

In 2002, the price of copper began to increase. By May 2006, copper prices rose above 7000\$/t, the highest they have been in real dollars since World War I and nearly two times the $20^{\text {th }}$ century average in real dollars. Short-term supply and demand misalignments, due to China's recent growth, and the inability of copper producers to ramp up production quickly enough have explained these recent price increases $(44,45)$. Production limitations have been linked to labor strikes and natural phenomena.

These price trends suggest that copper has become more vulnerable, mostly from an institutional efficiency aspect. However, according to Chapman and Roberts, a long term trend of physical constraint could manifest as a series of supply disruptions (21). For example, responding to spikes in demand for copper may be more difficult when reserve levels are low. The present supply-demand misalignments could therefore be viewed as reinforcing the above analysis of metrics, emphasizing the need for firms to become resilient to a copper geophysical constraint. A resilient supply chain should have a strategy that includes "what-if" plans for unplanned disruptions (46). The cobalt case-study suggests that a strategy for downstream supply chains should involve securing alternative material supplies (ex: increased recycling), and planning for materials substitution.

To secure copper supplies, supply chains need to have updated and accurate source information. Secondary copper information may be particularly difficult to obtain.

In the case of copper, relatively easy and secure substitutions have been developed in most major applications. Aluminum can substitute for copper in electrical wiring and heating/cooling systems, since aluminum supplies are abundant (reserve base/consumption $>250$ years). In plumbing applications, plastic pipes can substitute for copper. In telecommunication, fiber optics and wireless networks can replace copper. Substitution is expected to occur in the areas where technology and price make it most advantageous.

Finally, all the trends showing copper's increased vulnerability deserve continued close monitoring. Although we will not run out of copper, the copper supply is vulnerable to demand volatility. 


\section{Conclusions and Lessons Learned}

This document has presented two detailed cases that together highlight the interplay of raw materials availability and the supply chain. In particular, these have suggested:

1. Outcomes: specific changes which can be expected when limitations emerge;

2. Mechanisms: two mechanisms that can drive such limitations; and

3. Metrics: quantitative measures to provide insight on vulnerability.

This section will complement this with a preliminary discussion of prescriptions to make supply chains less vulnerable to such perturbations.

Those stakeholders that operate upstream are well aware of the capricious nature of raw materials and their impact on firm success. The cobalt case study illustrated that limitations in materials availability affected activities throughout the supply chain. Although changes in cobalt price emerged due to institutional-inefficiency, and were therefore temporary, materials substitutions and changes in mining and refining location remain.

Specifically, this paper suggests a range of outcomes that can be expected in response to availability-driven price increases. These include:

- technological: materials substitution can reduce demand for scarce materials ;

- technological: process change can improve conversion from resource to product

- geographic: mining exploration and source relocation can increase availability and reduce vulnerability;

- operational: transportation modes improve source access and lead times;

- operational: increased inventory can reduce vulnerability to access and price uncertainty;

- operational: development of a reverse supply chain can provide access to resources

Given the breadth of these effects, supply chain managers need to analyze the risks of materials availability changes and prepare for possible future problems. A preliminary framework for approaching this issue was developed in this report. Metrics were developed based on the literature and the case study of cobalt to screen for vulnerable materials sources. No single metric is without its limitations; it is advised that a combination of metrics should be considered as a first step for firms to identify potential issues.

\subsection{Supply Chain Prescriptions}

Dealing with risk and uncertainty is not new to supply chain managers. In fact, two areas of work exist which deal with these risks; the first deals with supply-demand coordination (47-49); the 
second deals with disruption (46,50-52). Materials scarcity, as defined here, relates mainly to disruption risk.

Increased awareness of the availability of all raw materials may be facilitated by using metrics. Along the supply chain, upstream stakeholders are the most pertinent source of accurate information; limiting the risk of speculation, unexpected price changes and the permanent changes that they can engender. Knowledge of government action, in particular for defense applications, can also be critical, as shown in the cobalt case.

Highlighting vulnerabilities through increased awareness is the first step towards investing in a plan to reduce vulnerability and deal with future disruptions. It is insufficient to list substitution as a future plan, rather, material selection decision-making should span the whole organization, affecting procurement, finances, marketing and manufacturing. In preparing for materials scarcity, this plan should include alternate sources of materials and should evaluate materials substitution options.

Another strategy is to add flexibility to the supply chain by having multiple suppliers and keeping inventory stocks $(46,50)$. In the case of materials, flexibility can also be added through substitution and recycling. Supply chain managers should be aware of possible substitutes, their attributes and required changes to make the substitution successful. Second, recycling can be an important alternative source of materials, but technological limitations to recycling do exist. It is important for supply chain managers to be aware of recycling possibilities and barriers for their products.

Knowledge, planning, and flexibility are three broad measures to reducing supply chain risks. Although, institutional inefficiency is the most likely type of materials availability problem for the supply chain in the near term, each of these measures can also prepare supply chains for long term risks of physical constraint. 


\section{References}

(1) Bureau of Labor Statistics; U.S. Department of Labor, 2006.

(2) Charles, E. In The New York Times: New York, 1999.

(3) Garth, J.; Eastin, I.; Edelson, J.; CINTRAFOR, 2004.

(4) Matos, G.; Wagner, L. Annu. Rev. Energ. Environ. 1998, 23, 107-122.

(5) Hotelling, H. The Journal of Political Economy 1931, 39, 137-175.

(6) Barnett, H. J.; Morse, C. Scarcity and growth; the economics of natural resource availability; Published for Resources for the Future by Johns Hopkins Press: [Washington], 1963.

(7) Dasgupta, P.; Heal, G. Rev. Econ. Stud. 1974, 3-28.

(8) Solow, R. M. The Americal Economic Review 1974, 64, 1-14.

(9) Cleveland, C. J. Ecol. Econ. 1993, 7, 123-157.

(10) Simpson, R. D.; Toman, M. A.; Ayres, R. U. Scarcity and growth revisited : natural resources and the environment in the new millennium; Resources for the Future: Washington, DC, 2005.

(11) Natural Resources Canada, 1886-2004.

(12) U.S. Geological Survey; U.S. Department of the Interior, 1932-2006.

(13) Blechman, B. M.; Sloss, D. National security and strategic minerals : an analysis of U.S. dependence on foreign sources of cobalt; Westview Press: Boulder, 1985.

(14) Odorn, L. C. T. P.; Institute, C. S., Ed.; U.S. Army Command and General Staff College: Fort Leavenworth, Kansas, 1993.

(15) Adelman, K. L. The Royal African Society, Oxford University Press 1978, 77, 36-44.

(16) Jolly, J. L.; 4th ed. ed.; Copper Development Association Inc.: New York, 2005; p 78.

(17) United Nations Statistics Division; United Nations Publications Board, 2006.

(18) Tilton, J. E. On borrowed time? : assessing the threat of mineral depletion; Resources for the Future: Washington, DC, 2003.

(19) Malthus, T. R.; 1st ed. ed.; J. Johnson: London, 1798.

(20) Ricardo, D.; 3rd ed. ed.; John Murray: London, 1821, first published 1817.

(21) Chapman, P. F.; Roberts, F. Metal resources and energy; Butterworths: London ; Boston, 1983.

(22) McClements, J.; Cranswick, R. E\&MJ 2001, 202, 28-37.

(23) Ruhrberg, M. Resources, Conservation and Recycling 2006, 48, 141-165.

(24) Ayres, R. U.; Ayres, L.; Råde, I. The life cycle of copper, its co-products and byproducts; Kluwer Academic: Dordrecht ; Boston, 2003.

(25) Brunetti, C.; Gilbert, C. L. Resources Policy 1995, 21, 237-254.

(26) Gordon, R. B. Toward a new Iron Age? : quantitative modeling of resource exhaustion; Harvard University Press: Cambridge, Mass., 1987.

(27) CRU International Ltd. In Mining, Minerals and Sustainable Development; International Institute for Environment and Development: London, UK, 2002; p 221.

(28) Roxburgh, N. Policy responses to resource depletion : the case of mercury; JAI Press: Greenwich, Conn., 1980. 
(29) Gordon, R. B.; Bertram, M.; Graedel, T. E. Proceedings of the National Academy of Sciences of the United States of America 2006, 103, 1209-1214.

(30) Hubbert, M. K.; National Research Council (U.S.) Committee on Natural Resources. Energy resources. A report to the Committee on Natural Resources of the National Academy of Sciences-National Research Council; National Academy of Sciences-National Research Council: Washington,, 1962.

(31) Tilton, J. E.; Landsberg, H. H. In Understanding Productivity Change in Natural Resource Industries; Discussion Paper 97-41 ed.; Future, R. f. t., Ed.; Resources for the Future: Washington, US, 1997; p 32.

(32) Tilton, J. E. Resources Policy 1999, 25, 197-204.

(33) Ernst, W. G. Earth systems : processes and issues; Cambridge University Press: Cambridge ; New York, 2000.

(34) Meadows, D. H.; Meadows, D. L.; Project on the Predicament of Mankind.; Potomac Associates. The limits to growth; a report for the Club of Rome's project on the predicament of mankind; Universe Books: New York,, 1972.

(35) Mikesell, R. F. Resources Policy 1995, 21, 127-131.

(36) Copper Development Association; Member of the International Copper Association: New York, 2006; Vol. 2006.

(37) MMSD In Mining, Minerals and Sustainable Development; Earthscan Publications Ltd.: London, UK and Sterling, VA, 2002.

(38) Lifset, R. J.; Gordon, R. B.; Graedel, T. E.; Spatari, S.; Bertram, M. Jom-Journal of the Minerals Metals \& Materials Society 2002, 54, 21-26.

(39) Reijnders, L. Resources, Conservation and Recycling 2003, 38, $59-66$.

(40) Pindyck, R. S. The Journal of Political Economy 1978, 86, 841-861.

(41) Graedel, T. E.; Van Beers, D.; Bertram, M.; Fuse, K.; Gordon, R. B.; Gritsinin, A.;

Kapur, A.; Klee, R. J.; Lifset, R. J.; Memon, L.; Rechberger, H.; Spatari, S.; Vexler, D. Environ. Sci. Technol. 2004, 38, 1242-1252.

(42) Wood, J. H.; Long, G. R.; Morehouse, D. R.; Department of Energy, 2004.

(43) Metals Economics Group In PDAC 2006 International Convention; Prospectors \& Developers Association of Canada, 2006.

(44) Stundza, T. Reed Business Information 2005, 134, 45-46.

(45) Adams, W. Mining Magazine 2006, Mining Annual Review 2006.

(46) Rice, J. B., Jr.; Caniato, F. Supply Chain Management Review 2003, September/October, 22-30.

(47) Fisher, M. L. H., Janice H.; Obermeyer, Walter R.; Raman, Ananth Harvard Business Review 1994, May/Jun, Vol. 72, 83-93.

(48) Fisher, M.; Hammond, J. H.; Obermeyer, W.; Raman, A. Production and Operations Management 1997, 6, 211-225.

(49) Lee, H. L.; Padmanabhan, V.; Seungjin, W. Sloan Management Review 1997, $38,93$.

(50) Sheffi, Y. International Journal of Logistics Management 2001, 12, 1.

(51) Simchi-Levi, D.; Snyder, L.; Watson, M. Supply Chain Management Review 2002, January/February, 11-12.

(52) Kleindorfer, P. R.; Saad, G. H. Production and Operations Management 2005, 14, 53-68. 